\title{
Natural Radioactive
}

Disequilibrium of

the Uranium Series

GEOLOGICAL SURVEY BULLETIN $1084-A$

This report concerns work done on behalf of the U.S. Atomic Energy Commission and is published with the permission of the Commission

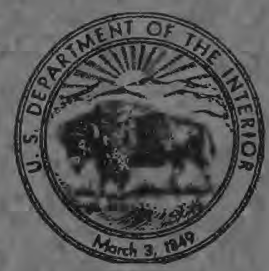




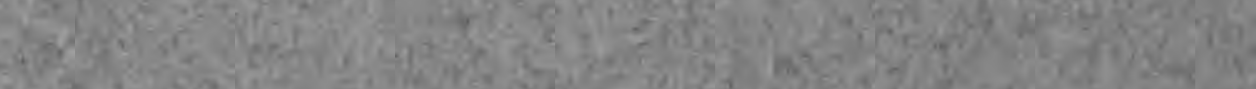

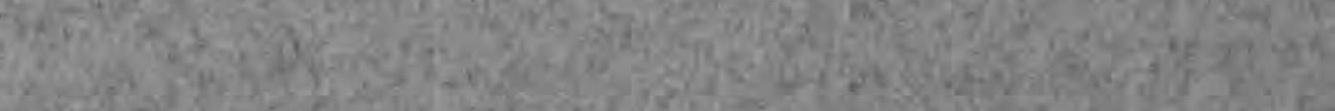

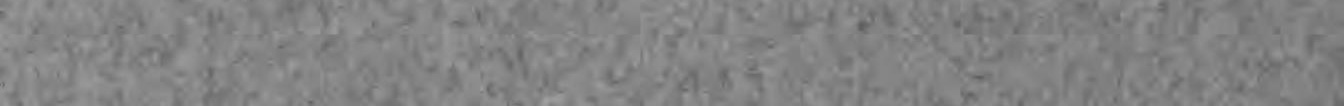
-

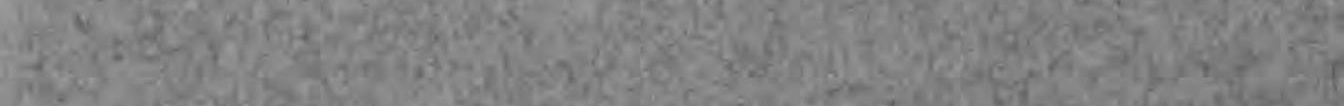

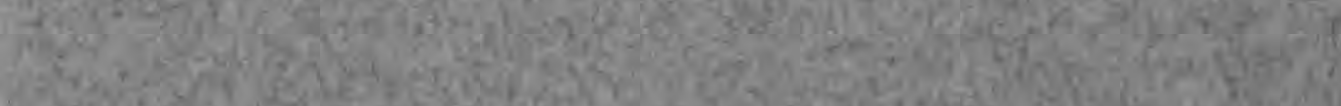
ar.

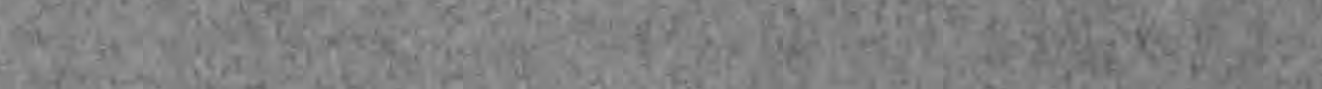

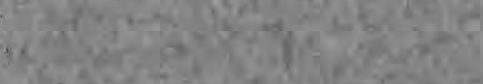

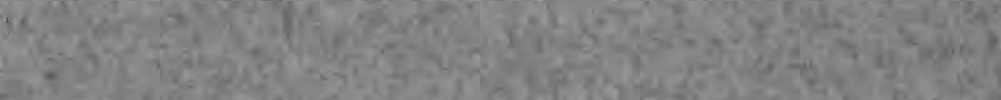

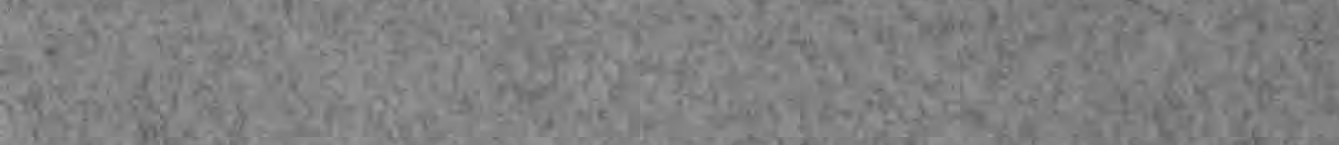

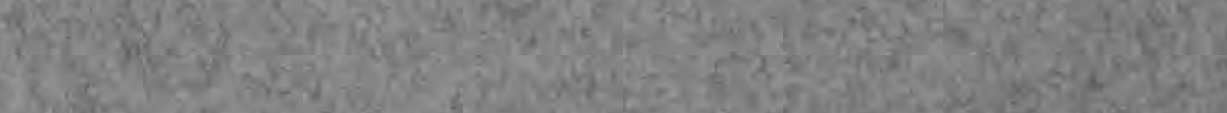
S.

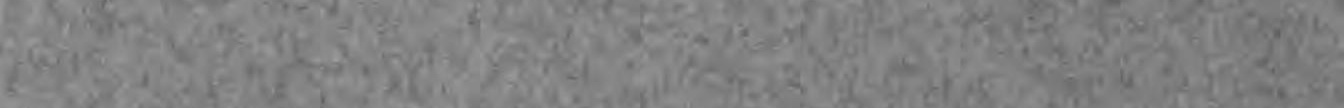

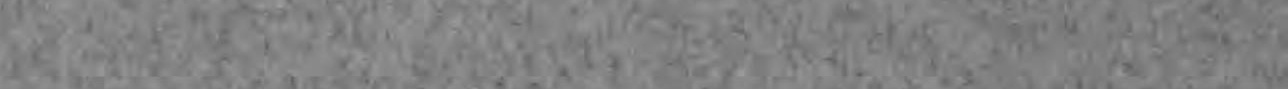

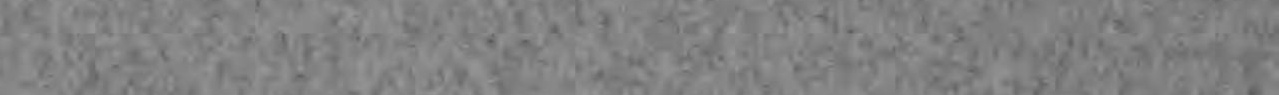
20) Q9.

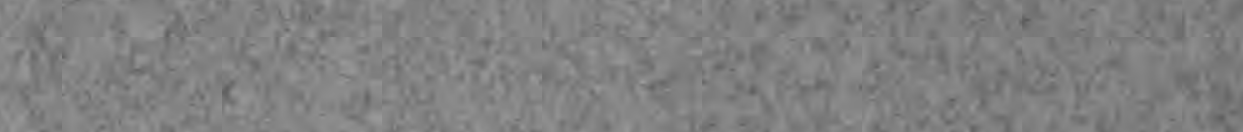
in

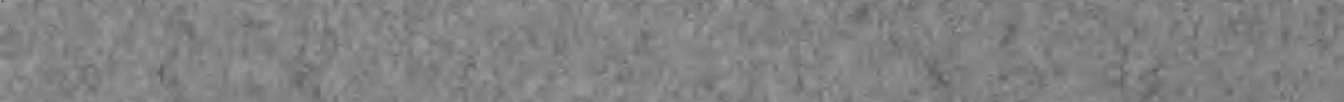
a

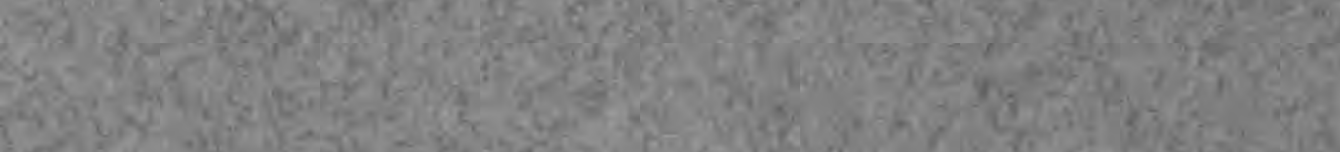
(4)

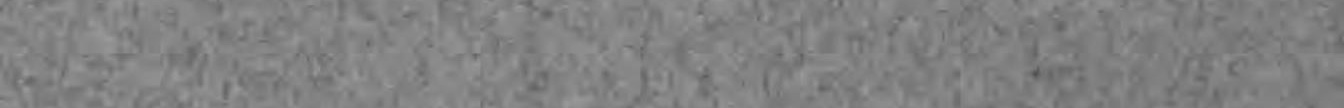

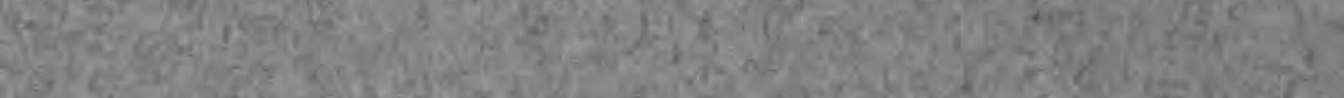

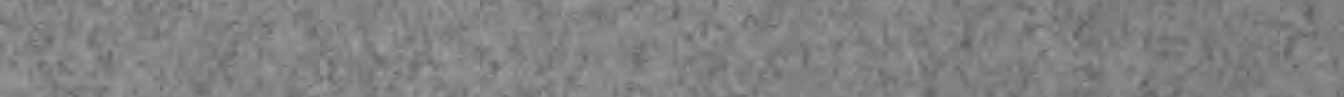

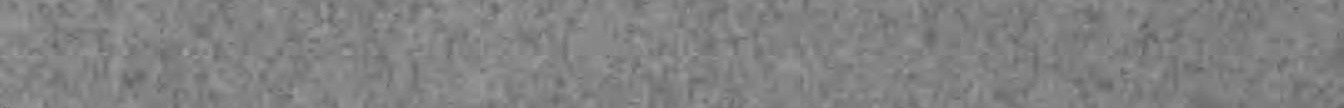

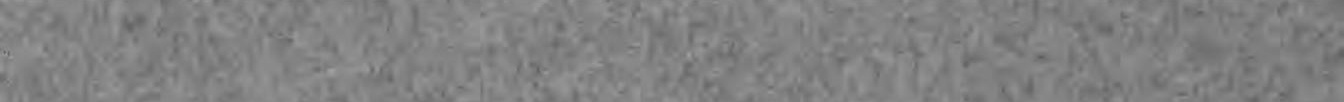

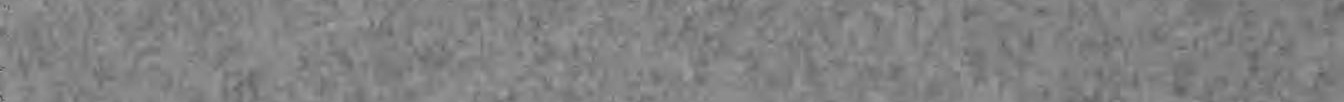

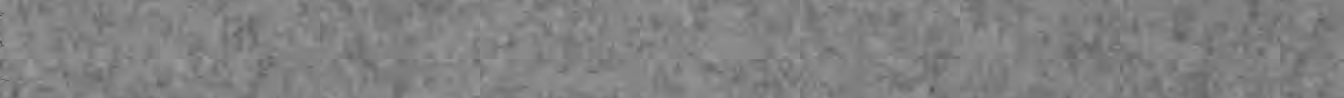

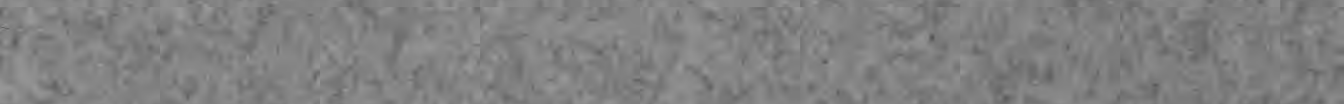

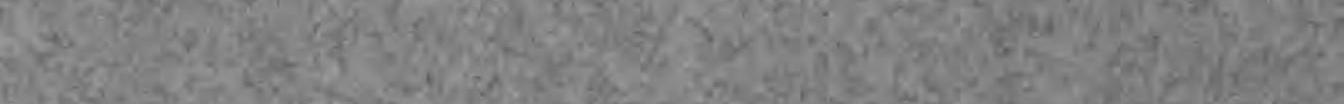

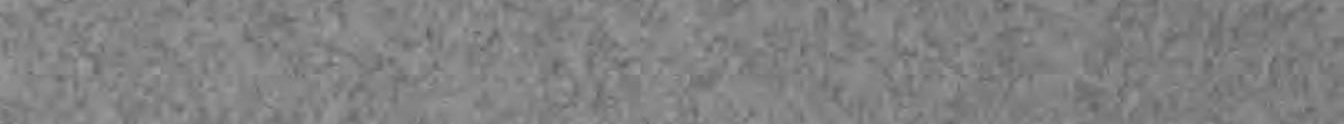

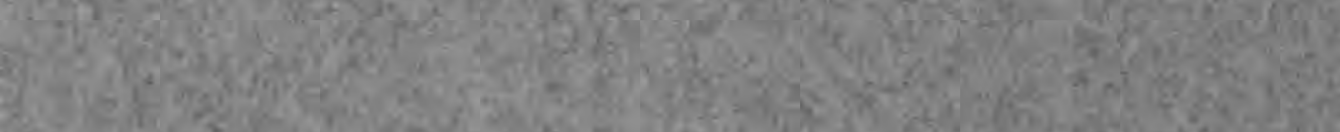

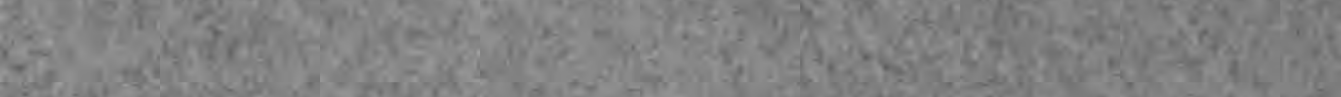
s.5. 


\section{Natural Radioactive}

Disequilibrium of

\section{the Uranium Series}

By JOHN N. ROSHOLT, Jr.

CONTR I B UTIONS TO GEOCHEMISTR Y

GE OL O G I A L S URVEY B ULLE T I N 1084-A

This report concerns work done on behalf of the U.S. Atomic Energy Commission and is published with the permission of the Commission

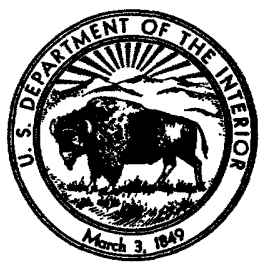




\section{UNITED STATES DEPARTMENT OF THE INTERIOR}

FRED A. SEATON, Secretary

\section{GEOLOGICAL SURVEY}

Thomas B. Nolan, Director

The Geological Survey Library has cataloged this publication as follows :

Rosholt, John Nicholas, 1923-

Natural radioactive disequilibrium of the uranium series. Washington, U. S. Govt. Print. Off., 1959.

iii, 30 p. diagrs., tables. $25 \mathrm{~cm}$. (U. S. Geological Survey. Bulletin 1084-A. Contributions to geochemistry)

Bibliography : p. 29-30.

1. Radioactivity. 2. Uranium. I. Title. (Series: U. S. Geological Survey. Bulletin 1084-A. Series: U. S. Geological Survey. Contributions to geochemistry)

553.493 


\section{CONTENTS}

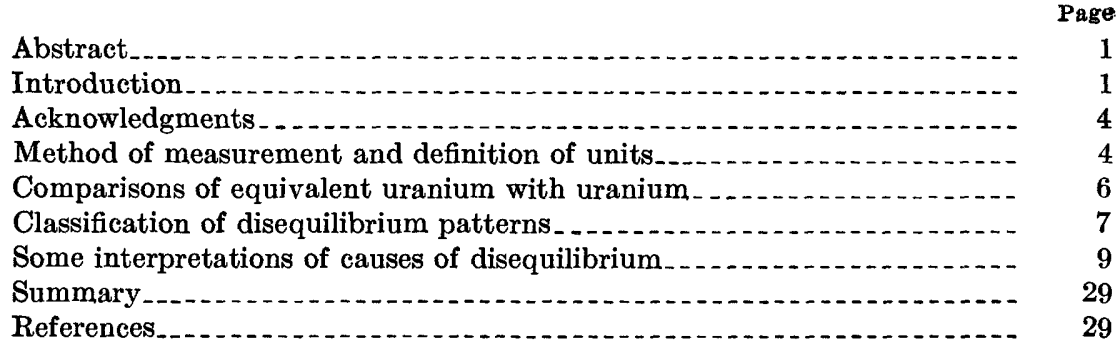

\section{ILLUSTRATIONS}

Figure 1. Classification of natural radioisotopes into groups

2. Anomalies in comparison of eU to $U \ldots \ldots$

3. Types of disequilibrium classified by ratios of radioisotopes_. $\quad 8$

4. Age of uranium deposition in years as a function of the ratios

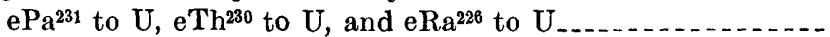

\section{TABLES}

TABLE 1. Age determination based on ratio of equivalent isotope to

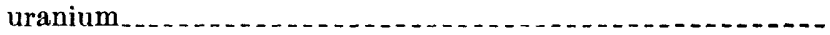

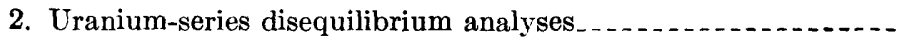





\title{
CONTRIBUTIONS TO GEOCHEMISTRY
}

\section{NATURAL RADIOACTIVE DISEQUILIBRIUM OF THE URANIUM SERIES}

\author{
By JoHN N. Rosholt, JR.
}

\section{ABSTRACT}

Many radioactive samples show radioactive disequilibrium because of the numerous geochemical processes affecting ore deposits. As it is difficult to interpret disequilibria by simply comparing radiometric and chemical assay values of uranium, analyses should be made of the abundance of $\mathbf{P a}^{231}, \mathbf{T h}^{230}$, $\mathrm{Ra}^{226}, \mathrm{Rn}^{222}$, and $\mathrm{Pb}^{210}$.

Uranium-series disequilibria, as shown by radiochemical studies of samples representing a cross section of most of the significant present-day radioactive deposits in the United States, can be classified according to six basic types. Interpretations of the geochemical history of these types indicate that it may be possible to date uranium deposition within a theoretical range of 2,000 to 200,000 years. Ages ranging between 6,000 and 30,000 years have been calculated for several specific samples.

\section{INTRODUCTION}

In the greatly expanded search for uranium in the last 10 years, disequilibrium in radioactive ores has presented a difficult problem to geologists and prospectors. The magnitude and frequency of disequilibria have been generally underestimated, although the importance of disequilibrium in field and laboratory counting measurements has begun to be realized.

Very few complete studies concerning disequilibrium in radioactive deposits have been published. Variations in the protactinium: uranium ratio have been reported by Schumb, Evans, and Hastings (1939) and Wildish (1930). Ratios of $\mathrm{Th}^{230}$ to uranium in coral limestone have been reported by Barnes, Lang, and Potratz (1956). A few results of analyses of $\mathrm{Ra}^{226}$ and $\mathrm{U}$ in mine-dump material have been given by Phair and Levine (1953). T. W. Stern and L. R. Stieff (1959) have reported several analyses of $\mathrm{Ra}^{226}$ and $\mathrm{U}$ in carnotite ores. Kuroda (1955) has provided a number of ratios of $\mathrm{Ra}^{223}$ to $\mathrm{Ra}^{226}$ in high-grade uranium minerals. Urry (1948) has reported several analyses of varved-clay samples containing radium. Other reports primarily on radium isotopes have been written by Armburst 
and Kuroda (1956), Koczy (1954), and Chlopin and Vernadsky (1932).

The purposes of this paper are to tabulate and discuss the results of a number of complete analyses of disequilibrium samples, to illustrate a proposed classification of disequilibrium patterns, to study these patterns as clues to the understanding of the geochemical history of the samples and of the deposits, and to point out some of the difficulties when simply comparing radioactivity and chemical analyses of uranium for interpreting equilibrium or disequilibrium in samples.

To make a detailed investigation of the state of radioactive equilibrium in ore-grade geologic samples, several key decay products must be measured and their relative abundances evaluated. Figure 1 shows the parent isotopes and decay or daughter products of the three principal naturally occurring radioactive decay series: the $\mathrm{U}^{238}$, $\mathrm{U}^{235}$, and $\mathrm{Th}^{232}$ series. Equilibrium is attained in a radioactive series when all the daughter products decay at the same rate that they are produced from the parent isotope. Thus, at equilibrium each of these daughter products would be present in a constant proportion to its parent isotope. The loss or gain, by geologic processes, of any of certain important isotopes during the more recent part of the existence of a mineral causes disequilibrium in the proportions of the parent isotope to its daughter products. Even though a series is not in complete equilibrium, many of the immediate short-lived daughter products will be in equilibrium with their long-lived parents. Where significant disruption of equilibrium occurs the natural radioisotopes can be separated into the following major isotopes and groups of established equilibrium shown in figure 1: the uranium group, $\mathrm{Th}^{230}$ isotope, $\mathrm{Ra}^{226}$ isotope, $\mathrm{Rn}^{222}$ group, $\mathrm{Pb}^{210}$ group, and $\mathrm{Pa}^{231}$ group in the uranium series. $\mathrm{U}^{235}$ itself will remain in constant abundance with $\mathrm{U}^{238}$ (Senftle and others, 1957); thus the $\mathrm{U}^{235}$ content is determined from the uranium analyses, which includes the isotopes $\mathrm{U}^{238}, \mathrm{U}^{235}$, and $\mathrm{U}^{234}$ which are assumed to be present in constant abundance to each other. In addition to these, the $\mathrm{Th}^{232}$ group may be present in some rocks and ores and add to the radioactivity.

To describe adequately the long-term state of equilibrium of the uranium series, the abundances of the long-lived isotopes, $\mathrm{U}, \mathrm{Pa}^{231}$, $\mathrm{Th}^{230}$, and $\mathrm{Ra}^{226}$ should be known. Analysis for $\mathrm{Rn}^{222}$ and $\mathrm{Pb}^{210}$, as well as for uranium, is desirable for investigating radioactivity anomalies, for checking the accuracy of uranium and radioactivity analyses, and for investigating emanation properties. With the exception of a few important samples, the results on ores containing significant quantities of $\mathrm{Th}^{232}$ are not included in this paper. Radiochemical assays by the author are given in table 2 at the end of the paper. 


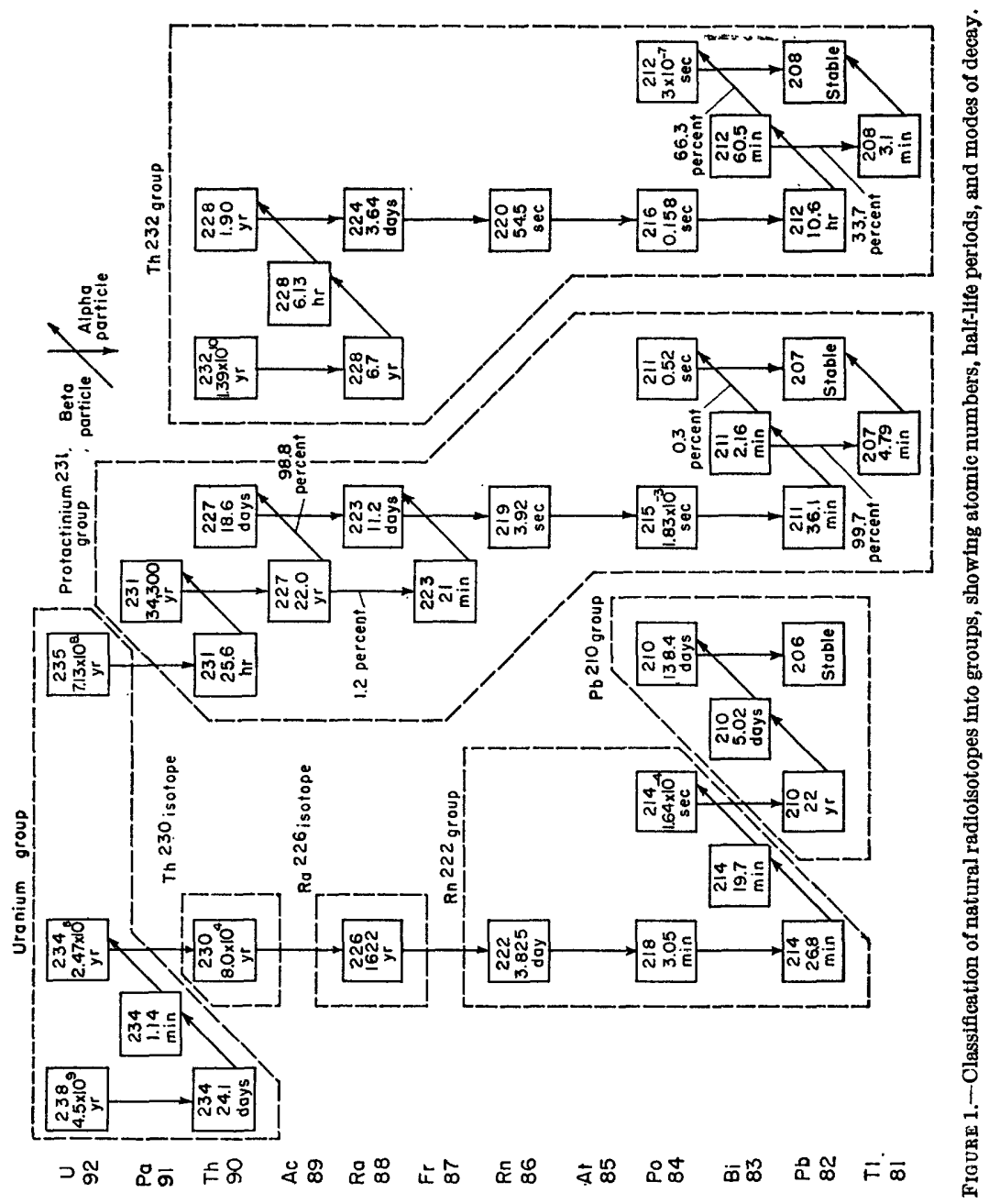




\section{ACKNOWLEDGMENTS}

Practically all the later analyses, which include the determination for $\mathrm{Pa}^{231}$, were made by using continuously operating automatic counting systems for parts of the alpha-activity measurements. These systems were designed and maintained by J. R. Dooley, without whose assistance much of this work could not have been completed at this. time. This work is part of a program being conducted by the U.S. Geological Survey on behalf of the Division of Raw Materials of the U. S. Atomic Energy Commission. A preliminary summary of this paper (Rosholt, 1957a) was presented at the Second Nuclear Engineering and Science Conference, Philadelphia, Pa., March 11-14, 1957.

\section{METHOD OF MEASUREMENT AND DEFINITION OF UNITS}

All the daughter-product analyses were made by alpha-particle measurements after radiochemical separations of the specific elements were made with the aid of inactive carriers. The abundance of the isotopes $\mathrm{Pa}^{231}, \mathrm{Th}^{230}, \mathrm{Ra}^{226}, \mathrm{Rn}^{222}$, and $\mathrm{Pb}^{210}$ was determined. The methods used for these analyses have been described by Rosholt (1954; 1957b).

Equivalent uranium, expressed in percent $\mathrm{eU}$, is the ratio of the radioactivity of the sample to the radioactivity of a uranium-ore standard which is in equilibrium with all of its decay products. Uranium is expressed as $\mathrm{U}$, in percent, and $\mathrm{Th}^{232}$ as $\mathrm{Th}^{232}$, in percent. All the decay products are expressed in percent equivalent and thus do not represent the actual amounts of these daughter products. Percent equivalent is defined as the amount, in percent, of primary parent, under the assumption of radioactive equilibrium, required to support the amount of daughter product actually present in the sample. This amount of primary parent may or may not be present in the sample. For the $\mathrm{Th}^{232}$ series, the daughter products are calculated as equivalent to $\mathrm{Th}^{232}$ and not to $\mathrm{U}$.

Some graphic examples of the definition of percent equivalent are shown in figure 2. The hypothetical sample in equilibrium is one showing 1 percent uranium, 1 percent $\mathrm{eU}$, and 1 percent equivalent of all of the daughter products; that is, 1 percent $\mathrm{ePa}^{232}, 1$ percent $\mathrm{e} \mathrm{Th}^{230}, 1$ percent $\mathrm{eRa}^{226}$, and so on. Sample 143 (Texas soil) has 0.65 percent $U$ and 0.96 percent $\mathrm{eTh}^{230}$. This $\mathrm{eTh}^{230}$ is present in excess of the uranium content and if equilibrium were to exist between $\mathrm{U}^{238}$ and $\mathrm{Th}^{230}$, then 0.96 percent $\mathrm{U}$ would be required in the sample. 


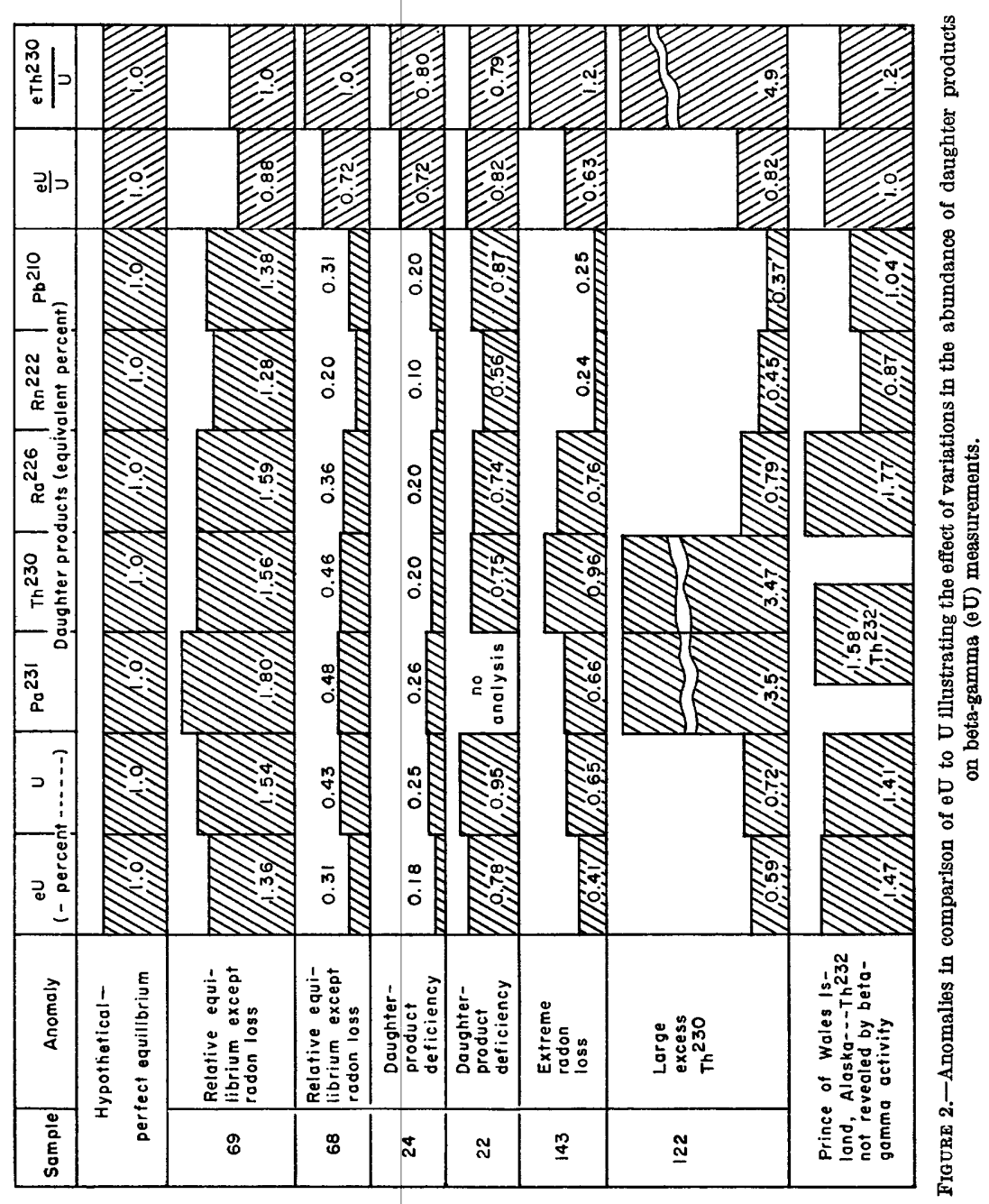


Other units which could be used to express this type of result are compared below with the equivalent units. As can be seen, the use of equivalent units simplifies recording and interpreting the data.

\begin{tabular}{|l|l|l|c|}
\hline \multicolumn{1}{|c|}{ Isotope } & $\begin{array}{c}\text { Percent } \\
\text { equivalent }\end{array}$ & Percent & $\frac{10^{-0} \text { curies }}{\text { grams of sample }}$ \\
\hline $\mathrm{U}^{238}$ plus $\mathrm{U}^{235}$ & 1.0 & 1.0 & 3.55 \\
$\mathrm{~Pa}^{231}$ & 1.0 & $3.37 \times 10^{-7}$ & .16 \\
$\mathrm{Th}^{230}$ & 1.0 & $1.70 \times 10^{-5}$ & 3.39 \\
$\mathrm{Ra}^{226}$ & 1.0 & $3.39 \times 10^{-7}$ & 3.39 \\
$\mathrm{Rn}^{222}$ & 1.0 & $2.15 \times 10^{-12}$ & 3.39 \\
$\mathrm{~Pb}^{210}$ & 1.0 & $4.28 \times 10^{-8}$ & 3.39 \\
\hline
\end{tabular}

The use of percent equivalent has other advantages besides that of illustrating or permitting direct comparison of uranium and daughterproduct abundances in the sample. It also demonstrates that an overall material balance of parent isotopes and daughter products must exist in theoretical equilibrium concentrations, although not necessarily in the concentrations of parent and daughter products found in the samples selected for examination. Stated again, percent equivalent is defined as the amount, in percent, of primary parent, under the assumption of radioactive equilibrium, required to support the amount of daughter product actually present in the sample. This amount of parent does not necessarily have to be present in the disequilibrium sample; actually more or less than that amount of uranium may be present. Thus the deficient amount of uranium or the deficient amount of daughter product, in relation to its immediate parent, must exist elsewhere than in the sample analyzed. To illustrate this principle with sample 143 (fig. 2), 0.96 percent $\mathrm{eTh}^{230}$ shows that there is a deficiency of $0.96-0.65$ or 0.31 percent uranium which must exist somewhere else unaccompanied by $\mathrm{Th}^{230}$; also, the sample is deficient of $0.76-0.24$ or 0.52 percent $\mathrm{eRn}^{222}$ and $0.76-0.25$ or 0.51 percent $\mathrm{ePb}^{210}$ which must exist elsewhere, unaccompanied by $\mathrm{Ra}^{226}$.

If a large enough sample is represented, the parent and all the daughter products will be present in equilibrium. However, this sample may have to be so large that it could not be collected. It also follows that the smaller the sample collected, the greater the probability of increasing the amount of disequilibrium found in the sample. This seldom considered assumption may be important in collecting samples.

\section{COMPARISONS OF EQUIVALENT URANIUM WITH URANIUM}

Although it is common practice to compare a sample's actual uranium content determined chemically with its equivalent uranium 
(eU), misinterpretations can be made in comparing these two values alone. Radon loss is the most common anomaly and may present some misleading conclusions. Figure 2 shows some examples. Two Colorado Plateau samples (Nos. 68 and 69) in relatively good equilibrium with the exception of some radon loss show eU:U ratios very similar to two other plateau samples (Nos. 22 and 24) which have a deficiency of $\mathrm{Th}^{230}$ and $\mathrm{Ra}^{228}$ together with a lesser radon loss. Thus the comparison of $\mathrm{eU}$ and $\mathrm{U}$ will not always indicate whether the sample is deficient in radon products alone or deficient in long-lived daughter products also. Some samples may even be deficient in uranium and still show a low eU:U ratio. Sample 143, of soil from Karnes County, Tex., illustrates this extreme case. The extremely high radon loss completely masks the presence of the long-lived daughters that are actually in amounts in excess of the uranium. The $\mathrm{eU}: \mathrm{U}$ ratio would indicate major disequilibrium with deficient amounts of daughter products, whereas actually it is the amount of uranium that is deficient.

A routine $\mathrm{e} U$ analysis will not indicate the presence of low-energy alpha emitters when beta-emitting daughter products are not present in the sample. Sample 122, a marl from the Nebraska-South Dakota border, illustrates this phenomenon. The large excess of $\mathrm{Th}^{230}$ and $\mathrm{Pa}^{231}$ is not indicated at all by the eU value because of the much lower $\mathrm{eRa}^{226}$ and $\mathrm{eRn}^{222}$ content. Sample 1 (table 2) exhibits a somewhat similar isotope distribution with a large excess of $\mathrm{Th}^{230}$, but a lower excessive content of $\mathrm{Pa}^{231}$. The eU analysis will not reveal the high $\mathrm{Pa}^{231}$ content which is evident in many samples, because of the lack of sufficient intensity of beta emission from this group.

In a routine $\mathrm{e} U$ analysis the radon loss may completely mask the additional radioactivity created by the presence of $\mathrm{Th}^{232}$ and its daughter products, as shown by two samples from Prince of Wales Island, Alaska. Only one is shown in figure 2, for they have very similar analyses; neither is listed in table 2 because they are primarily thorium ores, and complete disequilibrium analyses were not made on them. The eU:U ratio seems to indicate good uranium-series equilibrium, but actually the amount of $\mathrm{Th}^{232}$ and the percent equivalent of its daughter products are greater than those in uranium. Equivalent $\mathrm{Ra}^{226}$ is also in excess of the uranium content.

\section{CLASSIFICATION OF DISEQUILIBRIUM PATTERNS}

Study of the isotope-abundance ratios of samples exhibiting significant uranium-series disequilibrium shows that the various types seem to represent certain patterns. With the use of the analyses of the key isotopes $\mathrm{U}^{238}+\mathrm{U}^{235}, \mathrm{~Pa}^{231}, \mathrm{Th}^{230}$, and $\mathrm{Ra}^{226}$ it is proposed that practically all disequilibrium samples can be classified according to six 


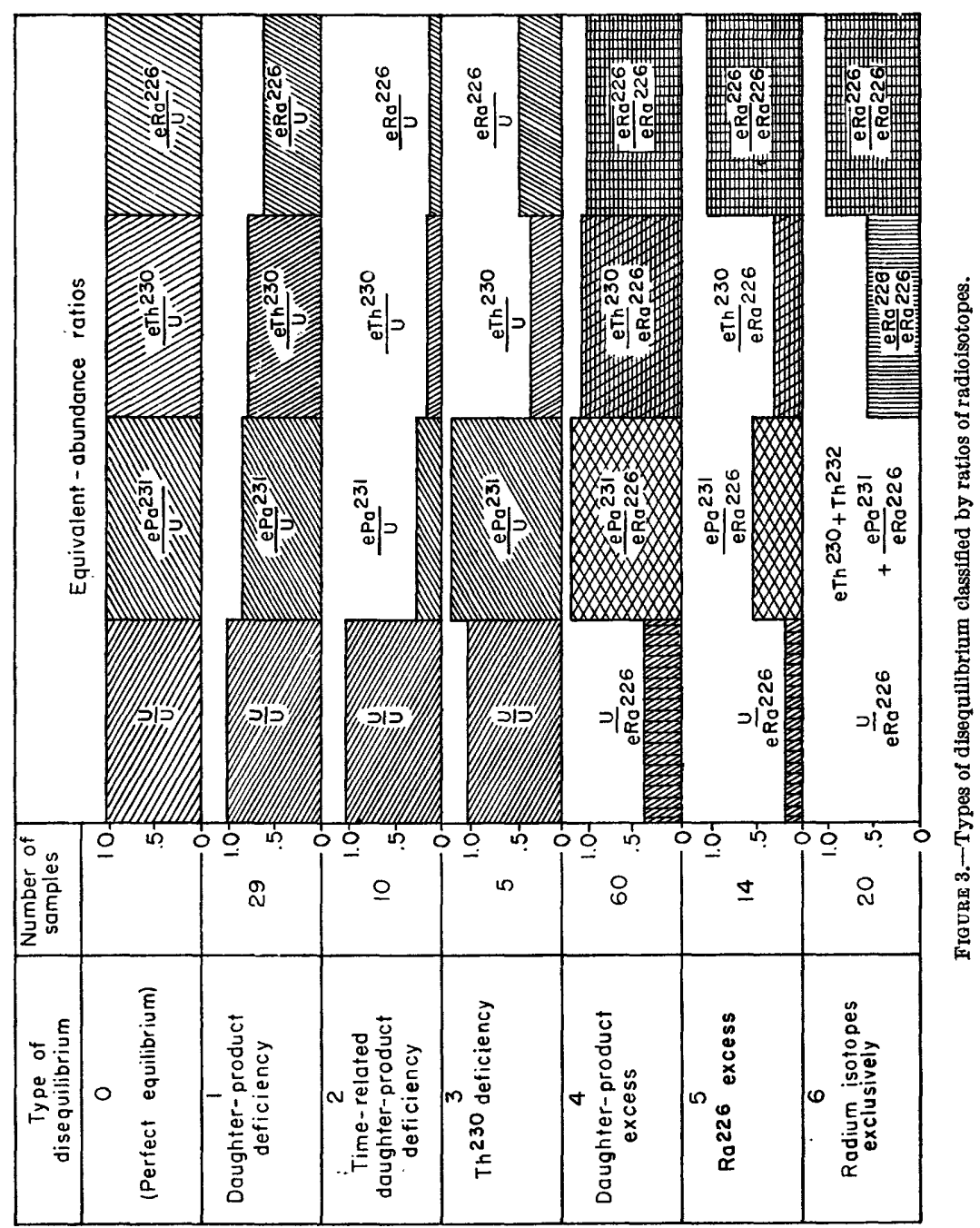


different types that can result from the most recent major process of alteration. The classification is shown in figure 3. The second column shows the number of samples that were analyzed and found to fall in each type; the equivalent-abundance ratios are the average values for the indicated number of samples. The first four rows of equivalent-abundance ratios, (types 0-3) show the comparison of equivalent daughter-product content to uranium content where the $\mathrm{U}: \mathrm{U}$ ratio is automatically 1 . The first row (type 0 ) represents the hypothetical sample of perfect equilibrium.

The first three types of disequilibrium have values of $U$ in excess of $\mathrm{eRa}^{226}$. Type 1, daughter-product deficiency, is represented by samples in which the generalized relationships are $\mathrm{U}>\mathrm{ePa}^{231}>\mathrm{eTh}^{230}>$ $\mathrm{eRa}^{226}$. Type 2, time-related daughter-product deficiency, is a very special kind of type 1 disequilibrium in which each of these daughter abundances must retain a specific relation with each other. This relation must be such that the amount of growth of each isotope from pure uranium, represented by the ratios of $\mathrm{ePa}^{231}$ to $\mathrm{U}, \mathrm{eTh}^{230}$ to $\mathrm{U}$, and $\mathrm{eRa}^{226}$ to $\mathrm{U}$, would require the same interval of time. Type 3, $\mathrm{Th}^{230}$ deficiency, is represented by samples in which generally $\mathrm{ePa}^{231}$ $\bar{\Sigma} \mathrm{U}>\mathrm{eRa}^{226}>\mathrm{eTh}^{230}$, the key isotope being the anomalously low $\operatorname{Th}^{230}$.

The last three types of disequilibrium have values of $\mathrm{eRa}^{226}$ in excess of $U$, and as the uranium content is so small, it and all the equivalent daughter-product abundances are compared to $\mathrm{eRa}^{226}$ instead of uranium, as in the first three categories. Type 4, daughterproduct excess, is represented by a low uranium content. The remaining longer lived daughter products are often present in approximately equilibrium amounts with one another. In some samples, however, the equivalent amounts of the daughter products vary considerably from one to another. Type $5, \mathrm{Ra}^{226}$ excess, as shown in dump material is a special case of type 4, daughter-product excess, where generally $\mathrm{eRa}^{226}>\mathrm{ePa}^{231}>\mathrm{eTh}^{230}$ which is much $>\mathrm{U}$, the key isotope being the significantly excessive $\mathrm{Ra}^{226}$. Type 6 , the occurrence of radium isotopes exclusively, is a peculiar and not too uncommon type of deposit in certain localities. Here $\mathrm{Ra}^{228}$, a daughter product of $\mathrm{Th}^{232}$, is commonly found with $\mathrm{Ra}^{226}$. The radioactive components are radium isotopes and their immediate decay products, and there is very little or no $\mathrm{U}, \mathrm{Th}^{230}, \mathrm{~Pa}^{231}$, or $\mathrm{Th}^{232}$.

\section{SOME INTERPRETATIONS OF CAUSES OF DISEQUILIBRIUM}

The study of the distribution of the radioactive decay products in the types of samples listed is still in its first stage; nevertheless it is 
possible to explain, or at least to postulate, some of the causes of disequilibrium.

Two primary processes can be involved in the type 1 ores. Uranium may have migrated to its present location at a time less than that required by its daughter products to reach approximate equilibrium, that is, less than 300,000 years ago. The alternative is that there has been preferentially greater leaching of daughter products than of uranium. The latter explanation is the more probable in carnotite and other types of deposits where uranium fixative agents such as vanadium or phosphate are also present. Samples of this kind (type 1) that do not follow the normal $\mathrm{U}>\mathrm{ePa}^{231}>\mathrm{eTh}^{230}>\mathrm{eRa}^{226}$ pattern (with $\mathrm{eRa}^{226}$ nearly equal to or only slightly less than $\mathrm{eTh}^{230}$ ) indicate that some leaching of daughter products has taken place. This kind of deficiency in daughter-product distribution is shown by samples $21,23,40,60,62,74,81,86,87,93,104,108,112,121,142$, and 144 (table 2). $\mathrm{Ra}^{226}$ has been found to be the most common, and, in most samples of this type, the only long-lived daughter product which can be leached. Deficiencies of $\mathrm{Rn}^{222}$ and $\mathrm{Pb}^{210}$ are not considered major causes of long-lived disequilibrium. When the isotope abundance is similar to that in type 2, considerable weight is thrown to the first explanation (recent deposition of uranium). This distribution is common in many of the pitchblende-type ores such as that at the Happy Jack mine. Samples 20, 22, 24, 35, 45, 47, 52, 57, 60, 61, 62, $73,86,87,104,107,118$, and 142 may represent this kind of alteration. Some of the samples may represent more recent uranium deposition than is indicated by the abundance of the isotopes (see fig. 4). That is, they may actually be type 2 material that was deposited where some older uranium minerals already existed, or uranium may have subsequently been leached out after the original, relatively recent, uranium deposition. Samples 60, 62, 86, 87, 104, and 142 could result from the combined effect of recent uranium deposition and leaching of $\mathrm{Ra}^{226}$.

Type 2 ores are of special significance because the isotope abundances are such that each isotope indicates nearly the same age for the uranium deposition. The required isotope abundances must match the time intervals when compared to figure 4. For the results of testing of these samples actually to represent the age of the uranium mineral, three conditions must be met: (a) uranium free of all decay products must have been deposited in nearly nonradioactive host rock, (b) there must have been no significant leaching of uranium or long-lived daughter products after deposition, and (c) the rate of deposition must not have been too slow compared to the rate of growth of daughter products. Evaluation of the effect of some of these conditions has been made (Rosholt, 1958). Table 1 shows the 


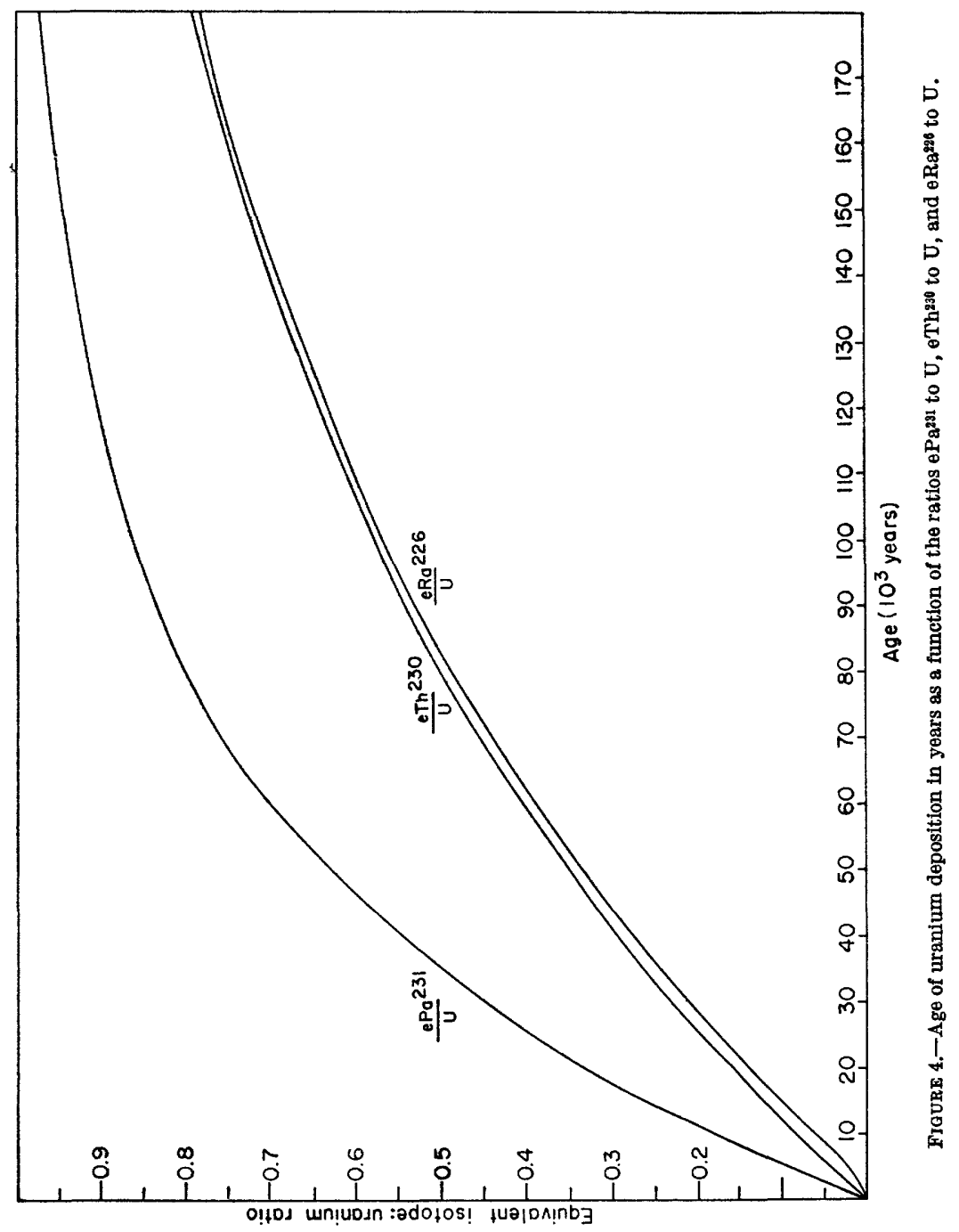


isotope ratios and the possible age of the uranium for all the samples represented by this category. Some anthropological evidence and carbon-14 measurements (Wendorf, Krieger, and Albritton, 1955) for the same stratigraphic location from which sample 141 was obtained support the premise that the age given in table 1 is of the correct order of magnitude. Type 2 disequilibrium is not very common, but increasing knowledge of favorable geochemical and geological environments is now providing a greater probability of locating ores of type 2 disequilibrium. Radiochemical data and field evidence are now being accumulated for a paper devoted primarily to geochemical interpretations based on this kind of disequilibrium.

TABLE 1.-Age determination based on ratio of equivalent isotope to uranium

\begin{tabular}{|c|c|c|c|c|c|c|}
\hline \multirow[b]{2}{*}{ Sample No.1 } & \multicolumn{3}{|c|}{ Isotope ratio } & \multicolumn{3}{|c|}{ Age (years) on the basis of- } \\
\hline & $\frac{\mathrm{ePa}^{231}}{\mathrm{U}}$ & $\frac{\mathrm{eTh}{ }^{230}}{\mathrm{U}}$ & $\frac{\mathrm{eRa}^{226}}{\mathrm{U}}$ & $\mathbf{P a}^{231}$ & $\mathrm{Th}^{230}$ & $\mathbf{R a}^{226}$ \\
\hline $\begin{array}{l}13 \\
14 \\
38 \\
53 \\
54 \\
55\end{array}$ & $\begin{array}{l}0.24 \\
.39 \\
.10 \\
.088 \\
.27 \\
.10 \\
.45 \\
.25 \\
.37 \\
.33\end{array}$ & $\begin{array}{l}0.13 \\
.26 \\
.053 \\
.022 \\
.15 \\
.045 \\
.18 \\
.15 \\
.26 \\
.18\end{array}$ & $\begin{array}{l}0.13 \\
.27 \\
.053 \\
.021 \\
.13 \\
.034 \\
.16 \\
.10 \\
.22 \\
.10\end{array}$ & $\begin{array}{r}14,000 \\
25,000 \\
5,000 \\
4,500 \\
16,000 \\
5,000 \\
30,000 \\
14,000 \\
23,000 \\
20,000\end{array}$ & $\begin{array}{r}16,000 \\
35,000 \\
6,000 \\
2,500 \\
18,000 \\
5,000 \\
23,000 \\
19,000 \\
35,000 \\
23,000\end{array}$ & $\begin{array}{r}18,000 \\
38,000 \\
9,000 \\
4,500 \\
18,000 \\
6,000 \\
22,000 \\
15,000 \\
31,000 \\
15,000\end{array}$ \\
\hline
\end{tabular}

1 See table 2 for description of sample.

Type 3 disequilibrium is believed to be the result of rather recent deposition of uranium contaminated with significant amounts of daughter products other than $\mathrm{Th}^{230}$, and with silica and salts. This type of disequilibrium is often the result of evaporation of solutions containing some of the long-lived isotopes, along with silica and various salts. The low $\mathrm{Th}^{230}$ content must reflect the relative deficiency of this isotope in the solutions. Sample 67, a hyalite-opal, appears to have this mode of origin. Samples 78,79 , and 80 , stratigraphically below three samples $(75,76$, and 77) of other classes, are most probably of this mode of origin (R. G. Coleman, oral communication).

Many samples with anomalously high radioactivity are of type 4. In general, disequilibrium of this type, found in samples taken from an oxidized environment, is the result of leaching of uranium. Daughter products may possibly have been added to the host rock, but it is difficult to select samples definitely showing that this occurred. A few samples $(4,36,37,42$, and 82$)$ have an abnormally low $\mathrm{eTh}^{230}$ content, which may indicate daughter-product addition when one considers that type 3 samples also have a low $\mathrm{eTh}^{230}$ content. A few samples $(1,46,49,71$, and 72$)$ have a low $\mathrm{ePa}^{231}$ content which may have resulted because sufficient time was available for a greater frac- 
tion of $\mathrm{Pa}^{231}$ than $\mathrm{Th}^{230}$ to decay after the uranium was leached. The fact that there is little $\mathrm{eRa}^{226}$ in many samples of this type does not appear to be too significant, for radium is easily leached in many different environments.

One very significant anomaly present in many samples of type 4, especially some of the high-grade black uranium minerals, is the high $\mathrm{Pa}^{231}$ content and near equilibrium abundances of $\mathrm{U}, \mathrm{Th}^{230}$, and $\mathrm{Ra}^{226}$. Samples 41, 59, 61, 65, 66, 68, 69, 89, and 144 show this anomaly. One explanation seems most plausible-uranium and the other decay products are preferentially leached to a greater degree than protactinium. This may be due to the greater ability of protactinium to become hydrolized and reprecipitated immediately from the leaching solutions (Elson, 1954). Additional possible evidence of this high $\mathrm{Pa}^{231}$ content in many uranium minerals is furnished by Kuroda (1955). The high ratios of $\mathrm{Ra}^{223}$ to $\mathrm{Ra}^{226}$ that are characteristic of many of the uranium minerals he analyzed may reflect a high $\mathrm{Pa}^{231}$ content.

Most of the samples represented by type 5 disequilibrium occur in pyritic ores or ore dumps and are the result of differential leaching of all components. Sulfates formed in these materials would retain the radium even though it might migrate somewhat, whereas the sulfuric acid formed would leach and remove uranium. Further discussion of this type of disequilibrium is presented by Phair and Levine (1953).

The occurrences of radium isotopes exclusively (type 6 disequilibrium) are commonly associated with oil- and gas-field brines. Radioactive hot-spring deposits also show this type of disequilibrium. These sometimes highly radioactive deposits are the result of coprecipitation of radium with barium sulfate, strontium sulfate, and occasionally iron hydroxide from large volumes of water. It is also believed that the reason for the deposition of radium isotopes, essentially free of other radioactive isotopes, is that the water contained only radium as a significant radioactive component. The radium is believed to come from the pore space of the country rock from which the water is flushed. Materials containing significant amounts of $\mathrm{Ra}^{228}$ (without $\mathrm{Th}^{232}$ ) must be of very recent origin, less than 30 or 35 years old. Samples 28, 127, 129, and 133-140 are of materials with recent additions of radium. Further evidence that many of these materials are of recent origin is the low $\mathrm{Pb}^{210}$ content. Sample 128 is a drill cutting from a depth of 2,530 feet and was obtained from rock below a well which was first drilled approximately 25 years ago (A. P. Pierce, oral communication). The well was deepened recently when the sample was collected. The ratio of $\mathrm{Pb}^{210}$ to $\mathrm{Ra}^{226}$ yields an age of 24 years. Further work describing many of the other aspects of oil-field radioactivity is presented by Gott and Hill (1953). 


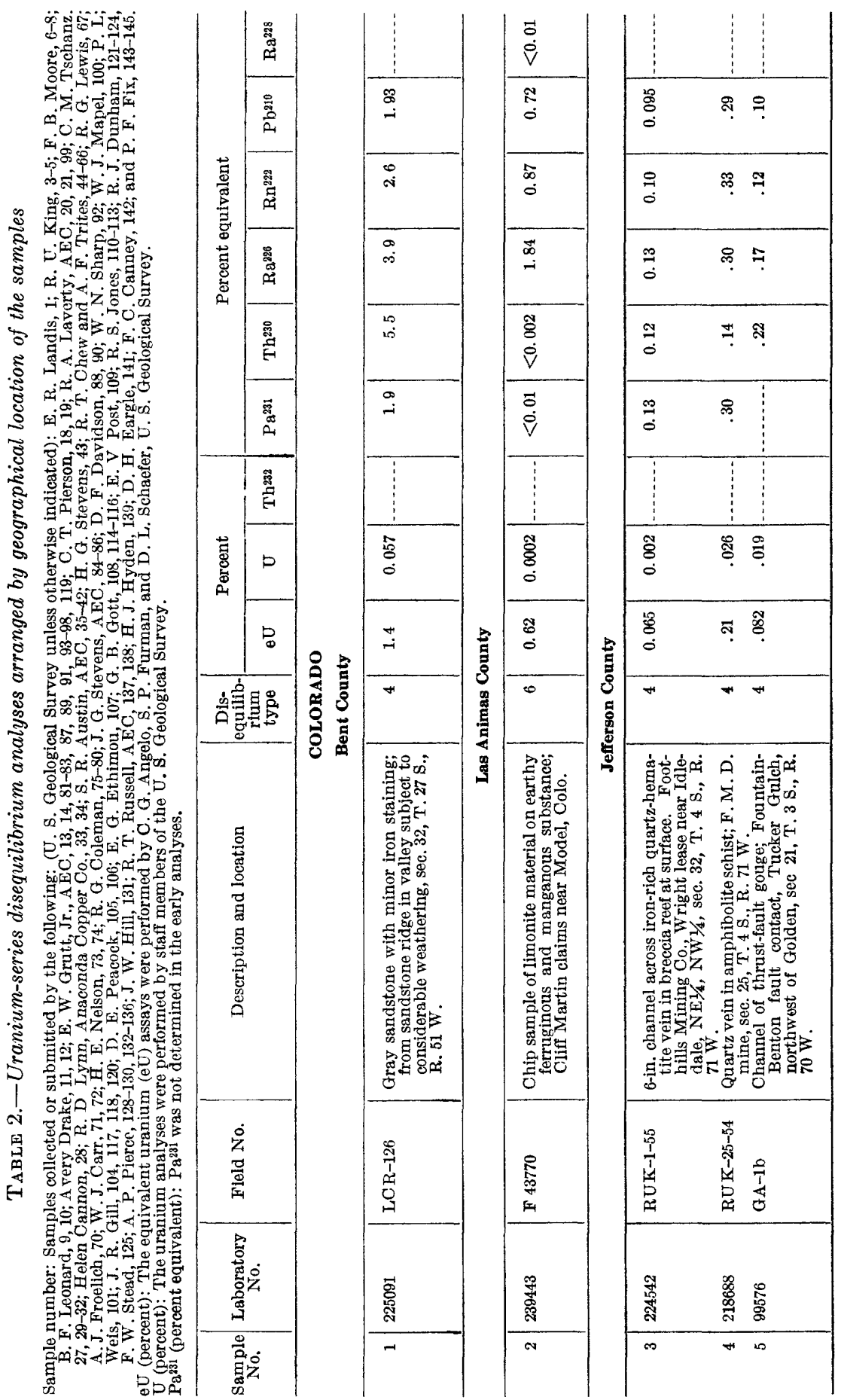



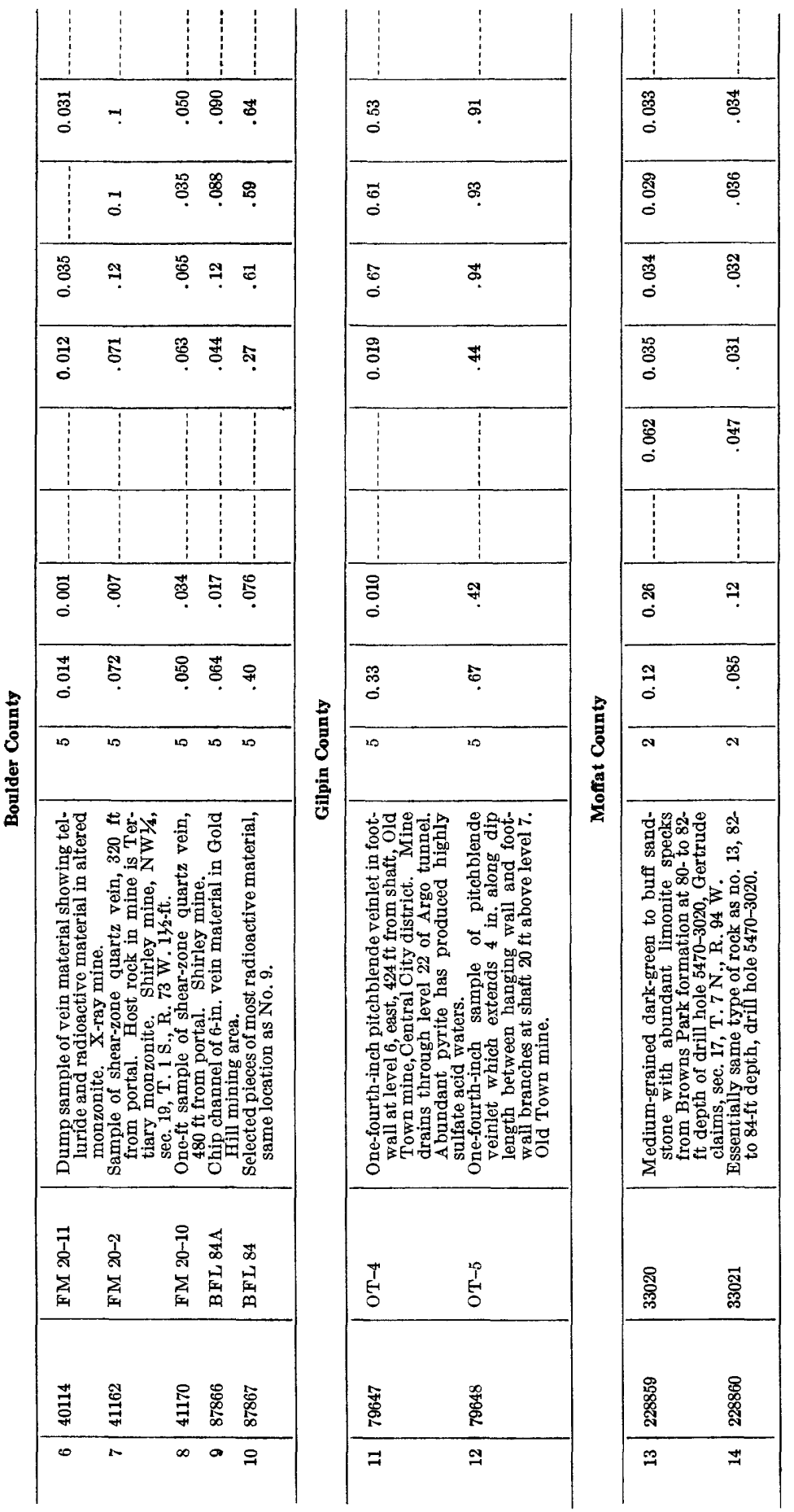


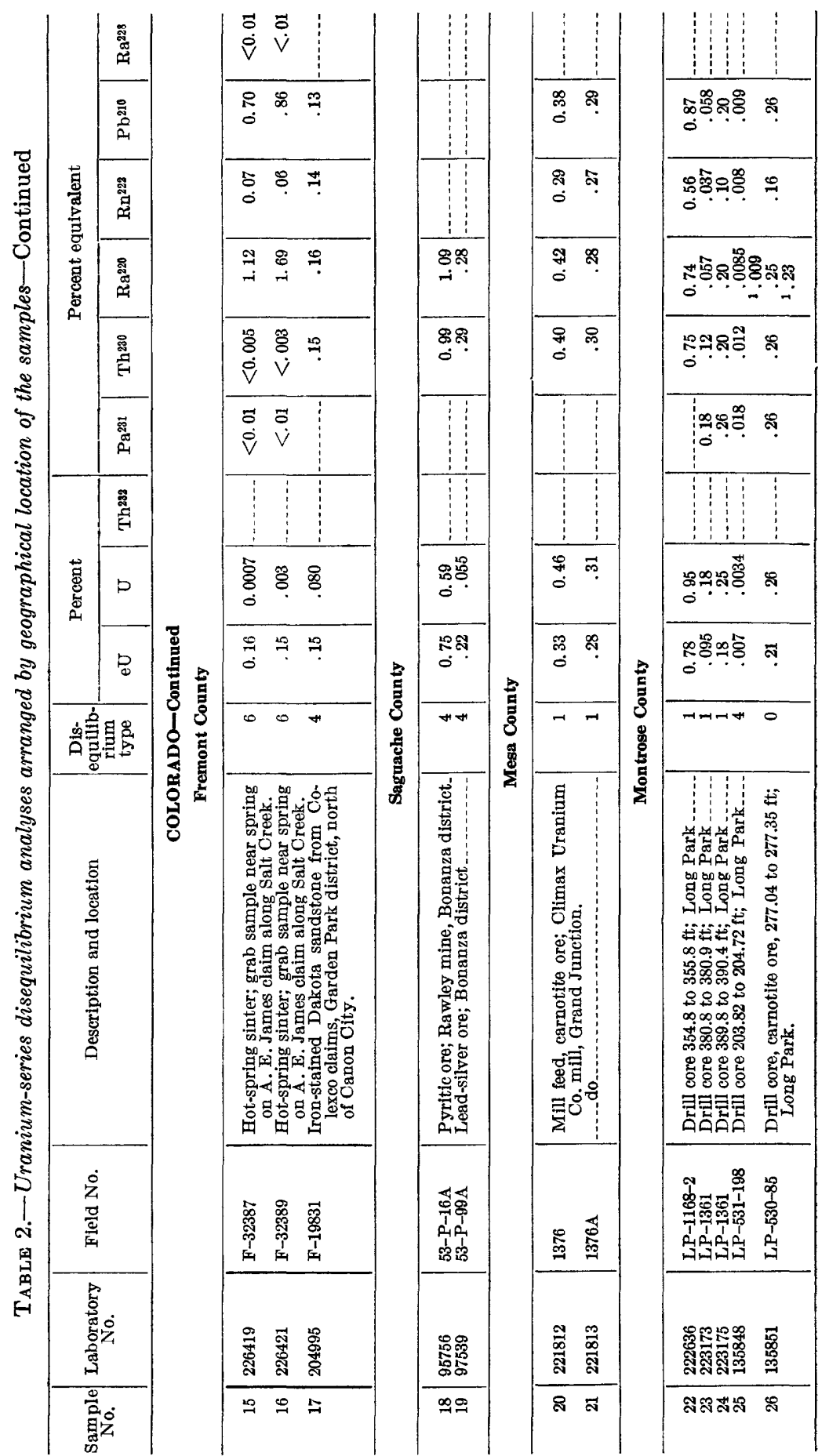


RADIOACTIVE DISEQUILIBRIUM OF THE URANIUM SERIES

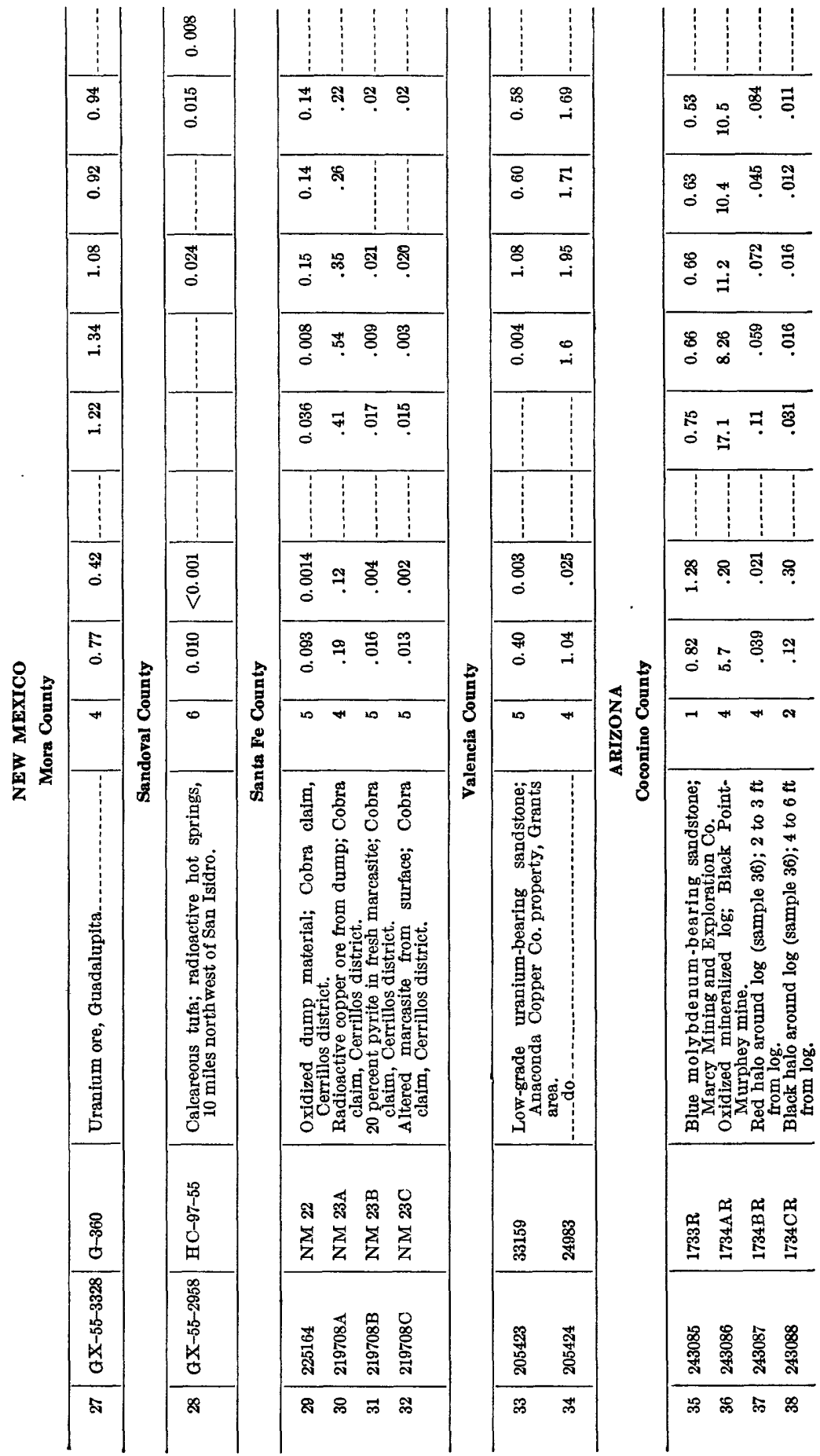



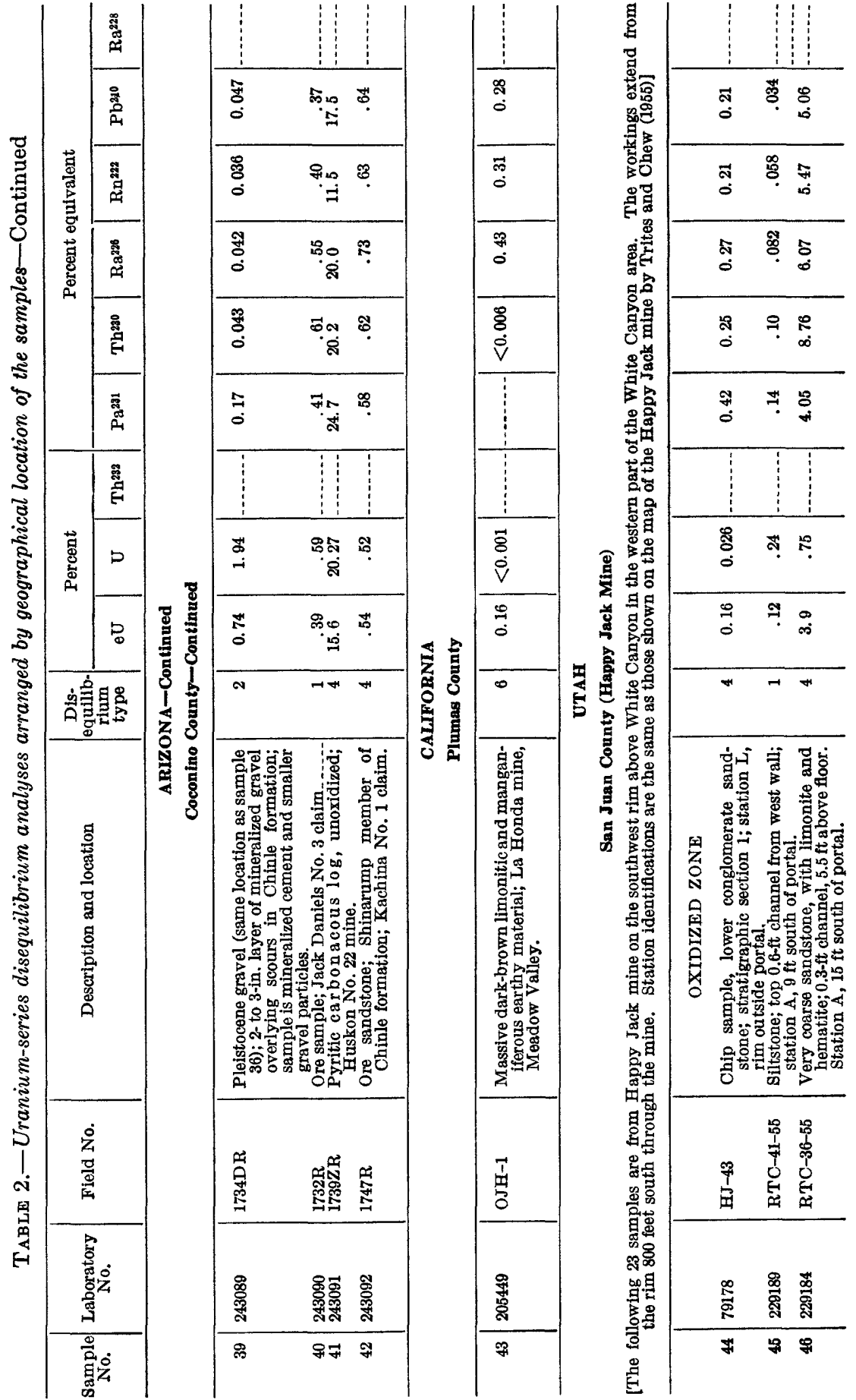


\begin{tabular}{|c|c|c|c|c|c|c|c|c|c|c|c|}
\hline$\stackrel{9}{?}$ & $\stackrel{\infty}{\Im}$ & $?$ & లై & $\stackrel{?}{?}$ & : & 苋 & 용 & ส్ర & $\stackrel{\infty}{\stackrel{\infty}{-}}$ & శุ. & ఈ ซึ \\
\hline
\end{tabular}

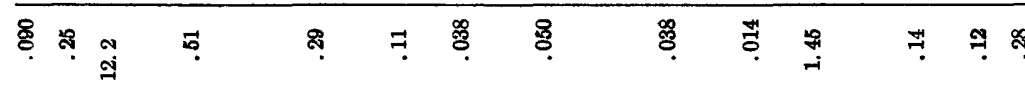

\begin{tabular}{|c|c|c|c|c|c|c|c|c|c|c|c|c|}
\hline$\cong$ & ๙ొ. & $\exists$ & ஜீ. & $\stackrel{\infty}{\infty}$ & $\stackrel{9}{9}$ & : & :̊ํํ & 융 & ธิ & $\stackrel{8}{\leftrightarrows}$ & ذุ & $\because$ \\
\hline สี & ஜొ & $\begin{array}{l}\circ \\
\stackrel{0}{a}\end{array}$ & $\stackrel{8}{\stackrel{-}{-1}}$ & 吊. & สุ & \% & 可 & 영 & $\not$ & $\stackrel{\circledast}{\rightarrow}$ & \&্ & 구 ำ ำ \\
\hline
\end{tabular}

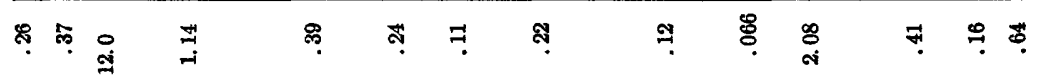

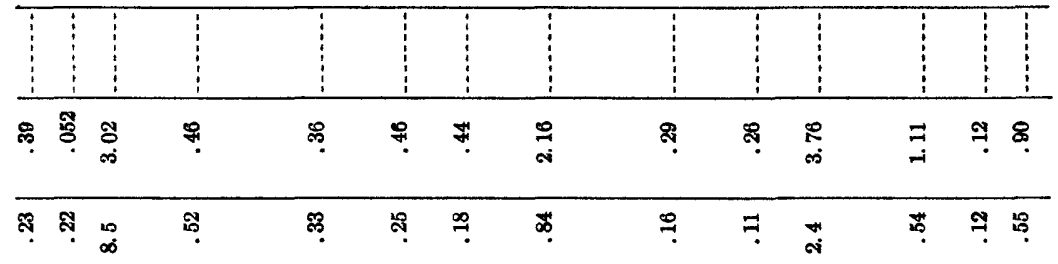

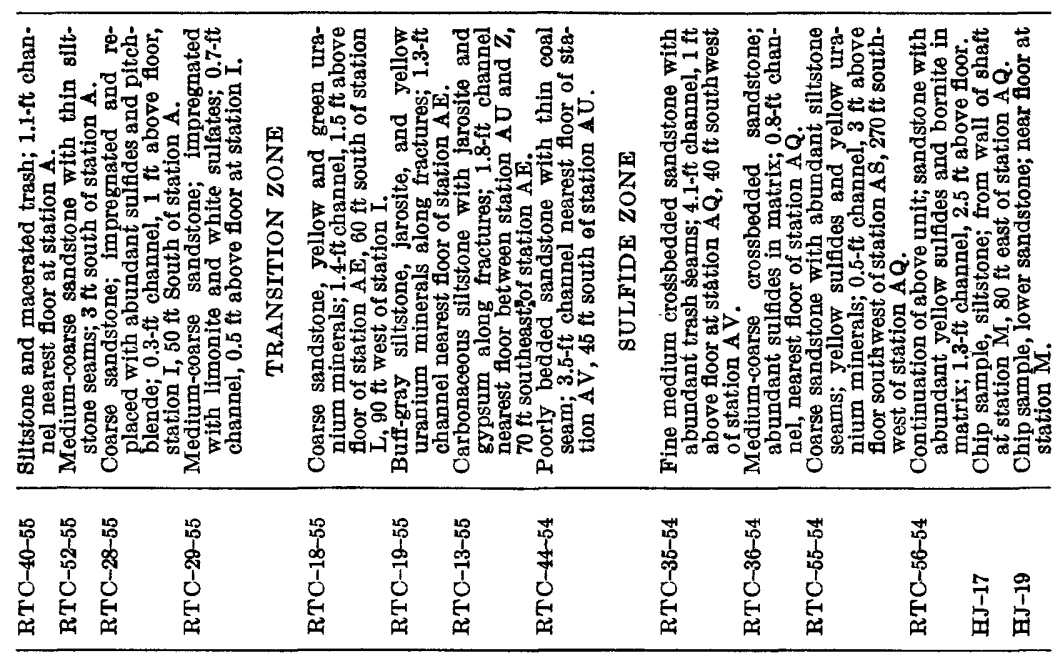

\begin{tabular}{|c|c|c|c|c|c|c|c|c|c|c|}
\hline 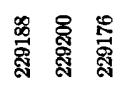 & 矛 & 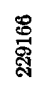 & 兽 & 急 & 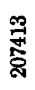 & 站 & 总 & 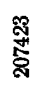 & 荵 & 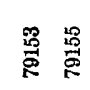 \\
\hline$\stackrel{9}{9}$ & 용 & $\overrightarrow{60}$ & 임 & 8 & 落 & 8 & $\not 8$ & in & $\mathscr{8}$ & 8 \\
\hline
\end{tabular}




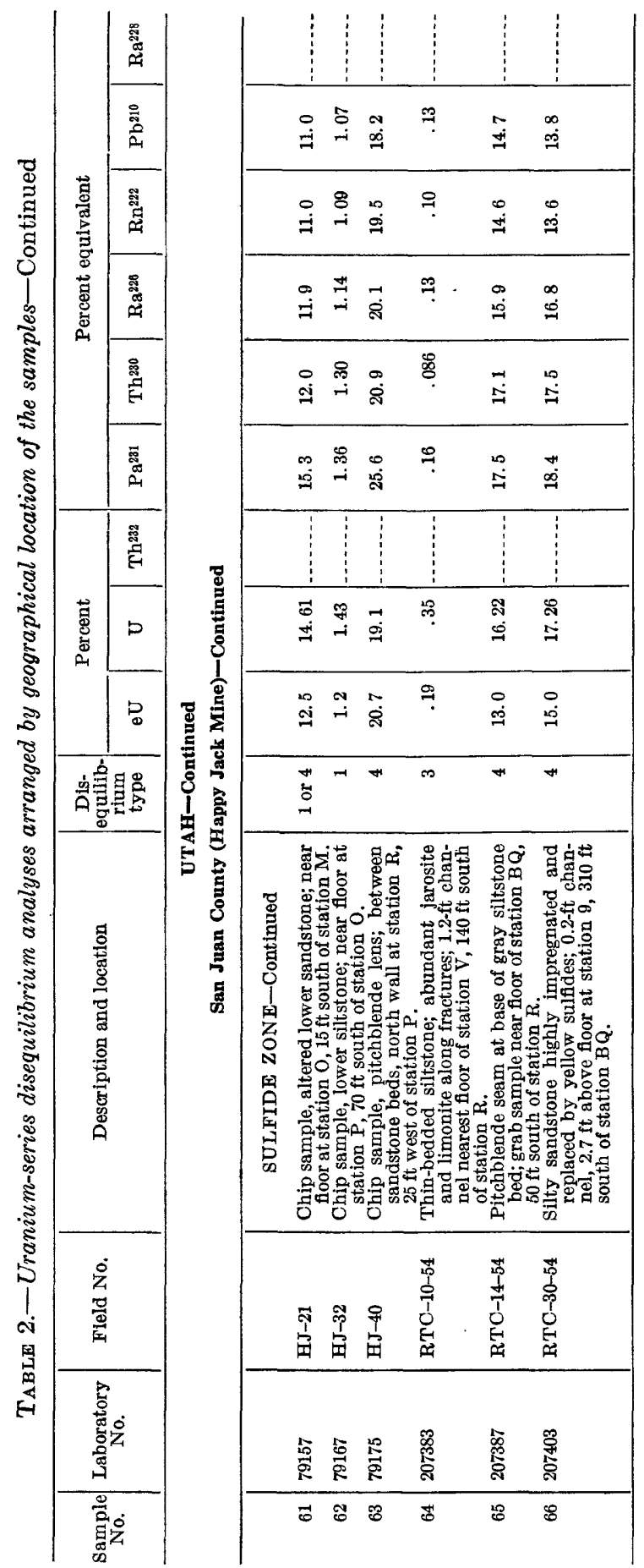

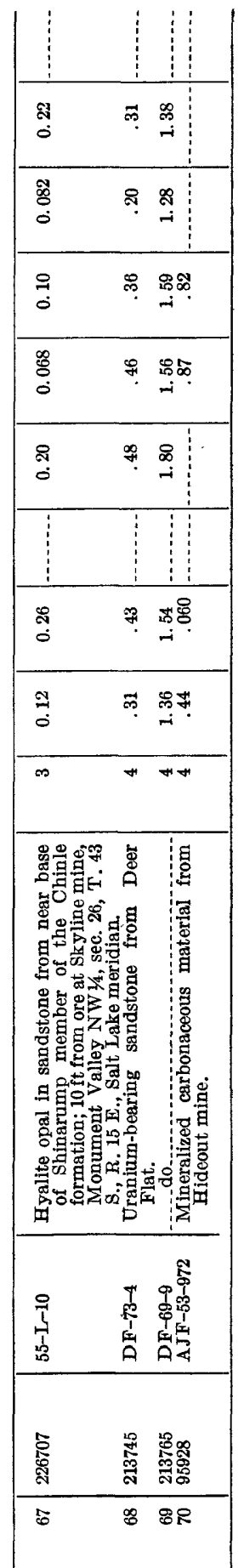




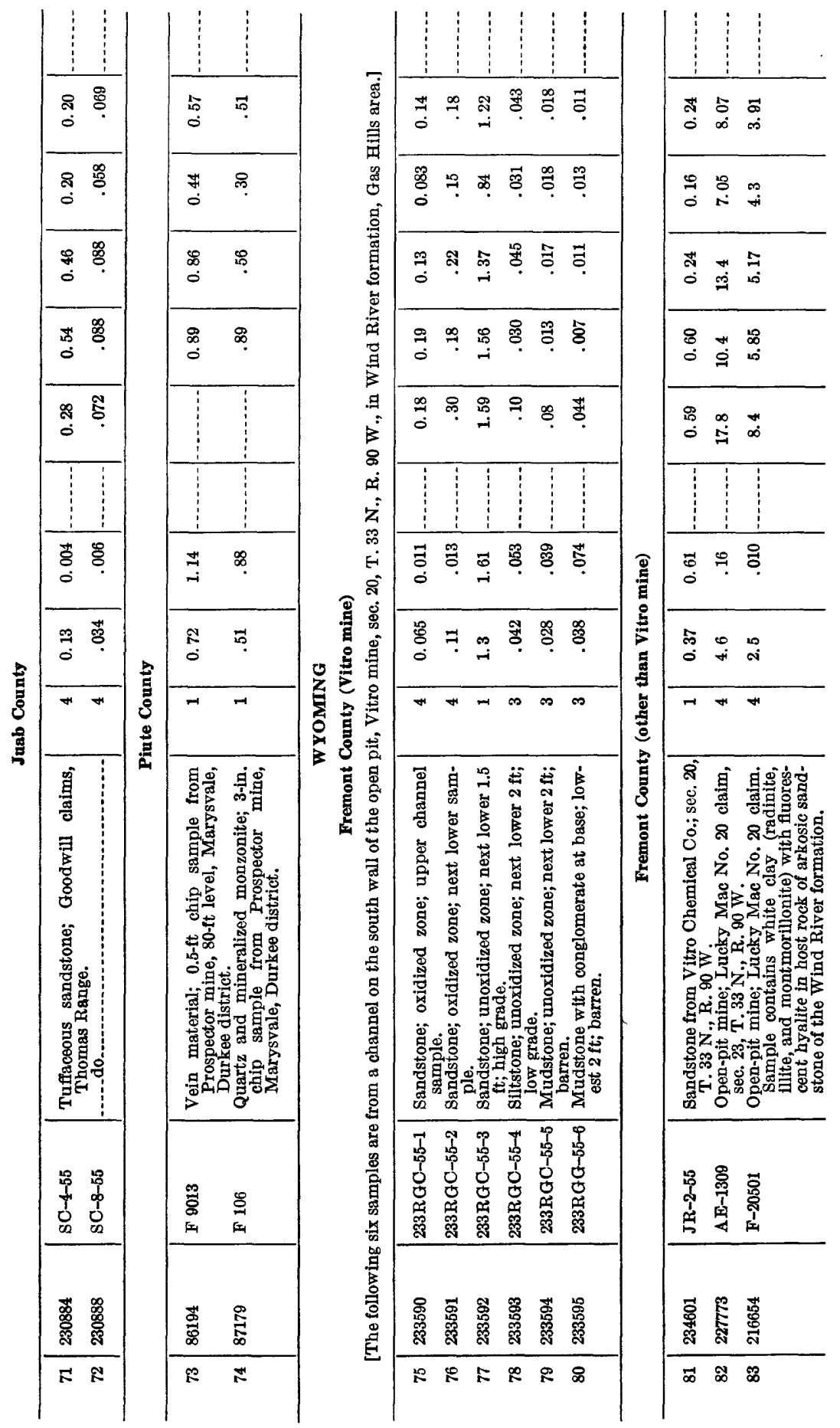




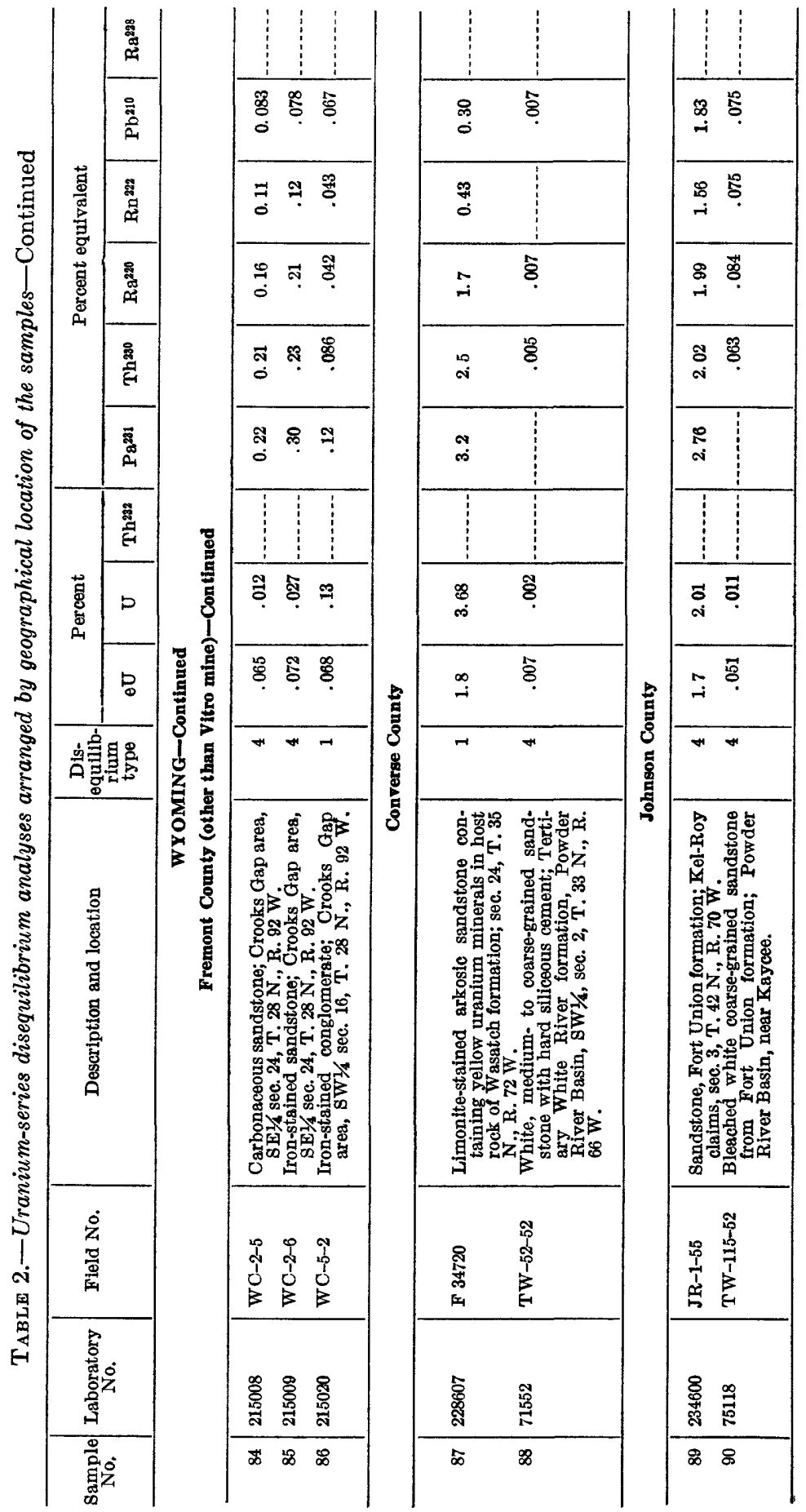




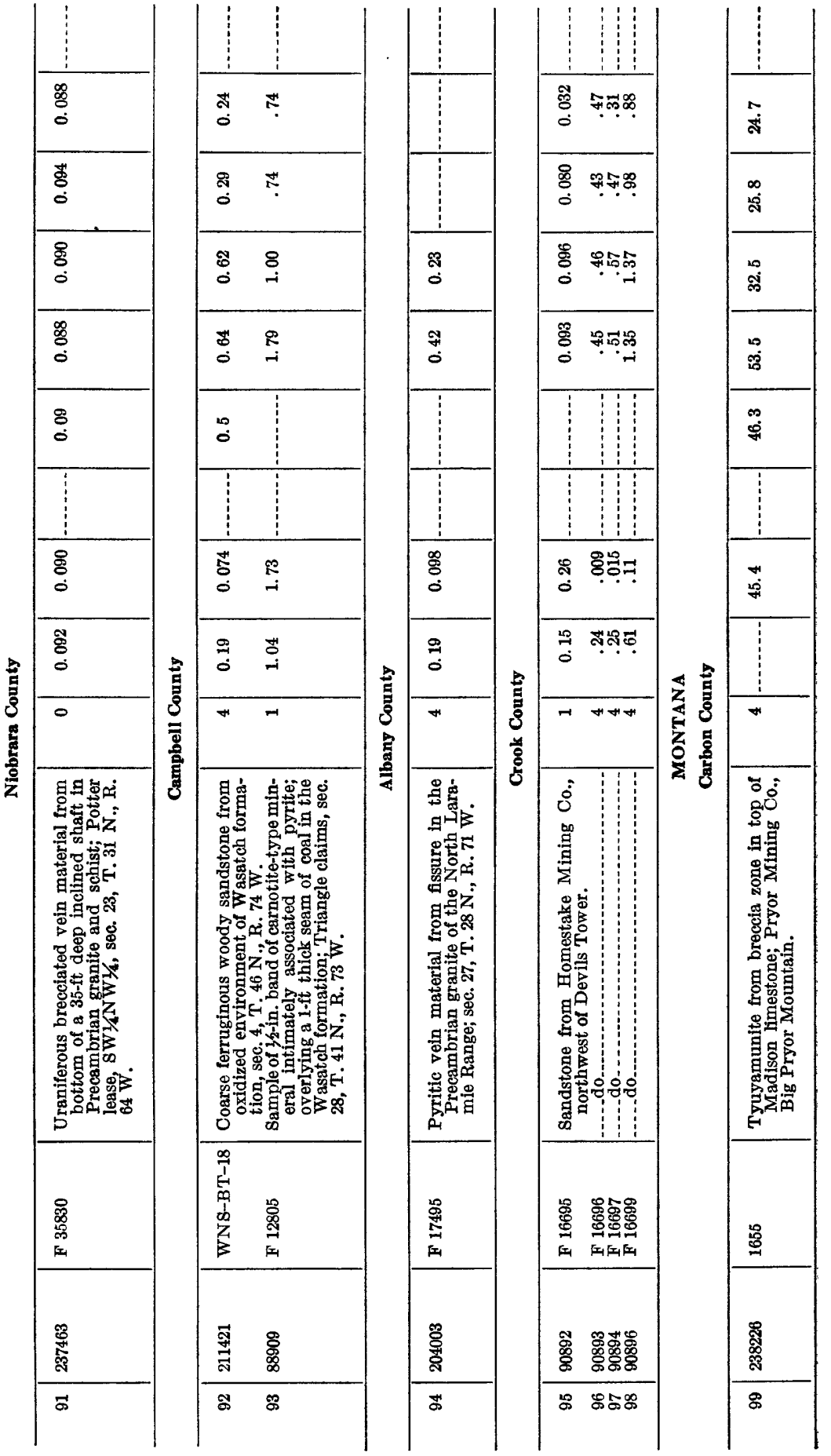




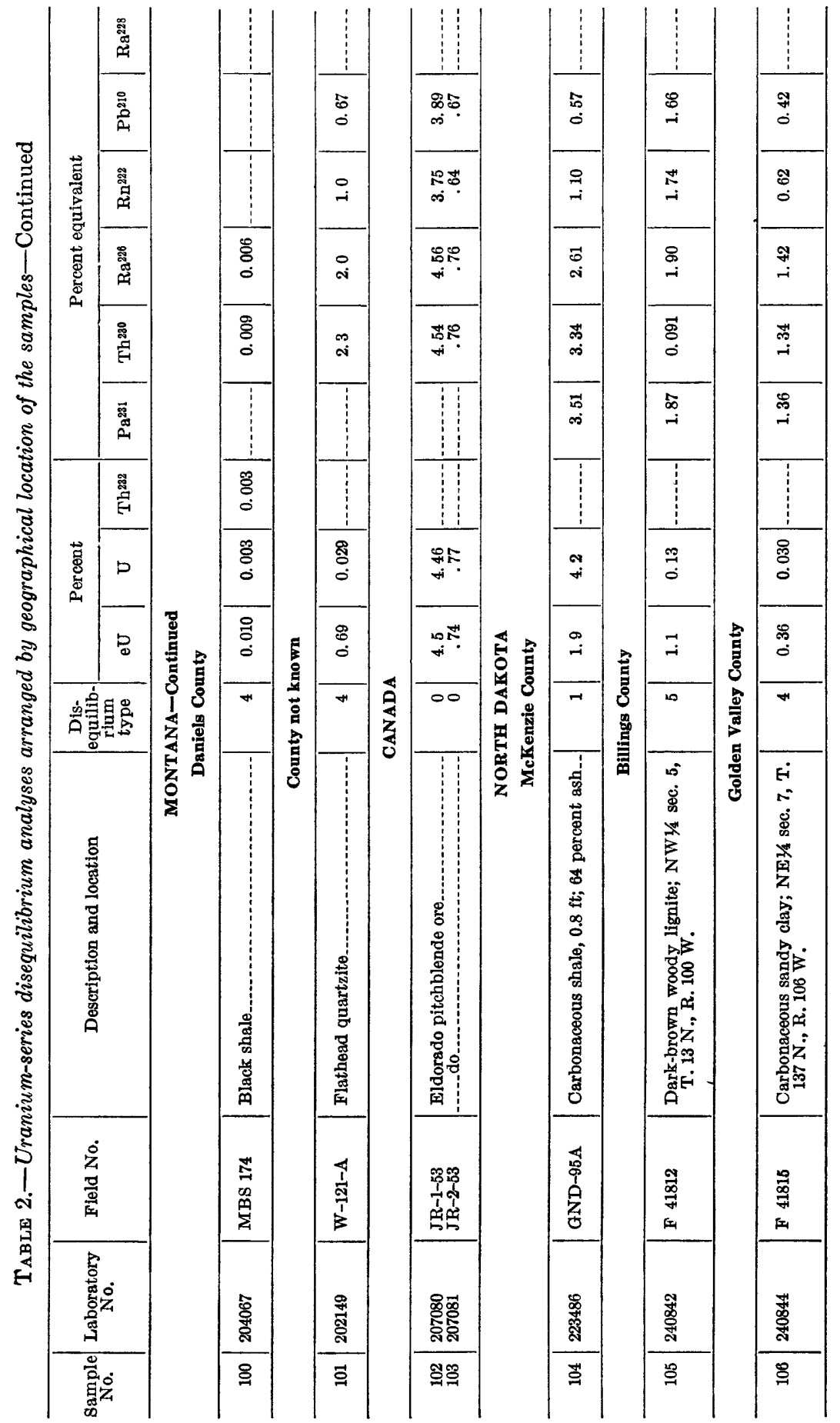


RADIOACTIVE DISEQUILIBRIUM OF THE URANIUM SERIES 25

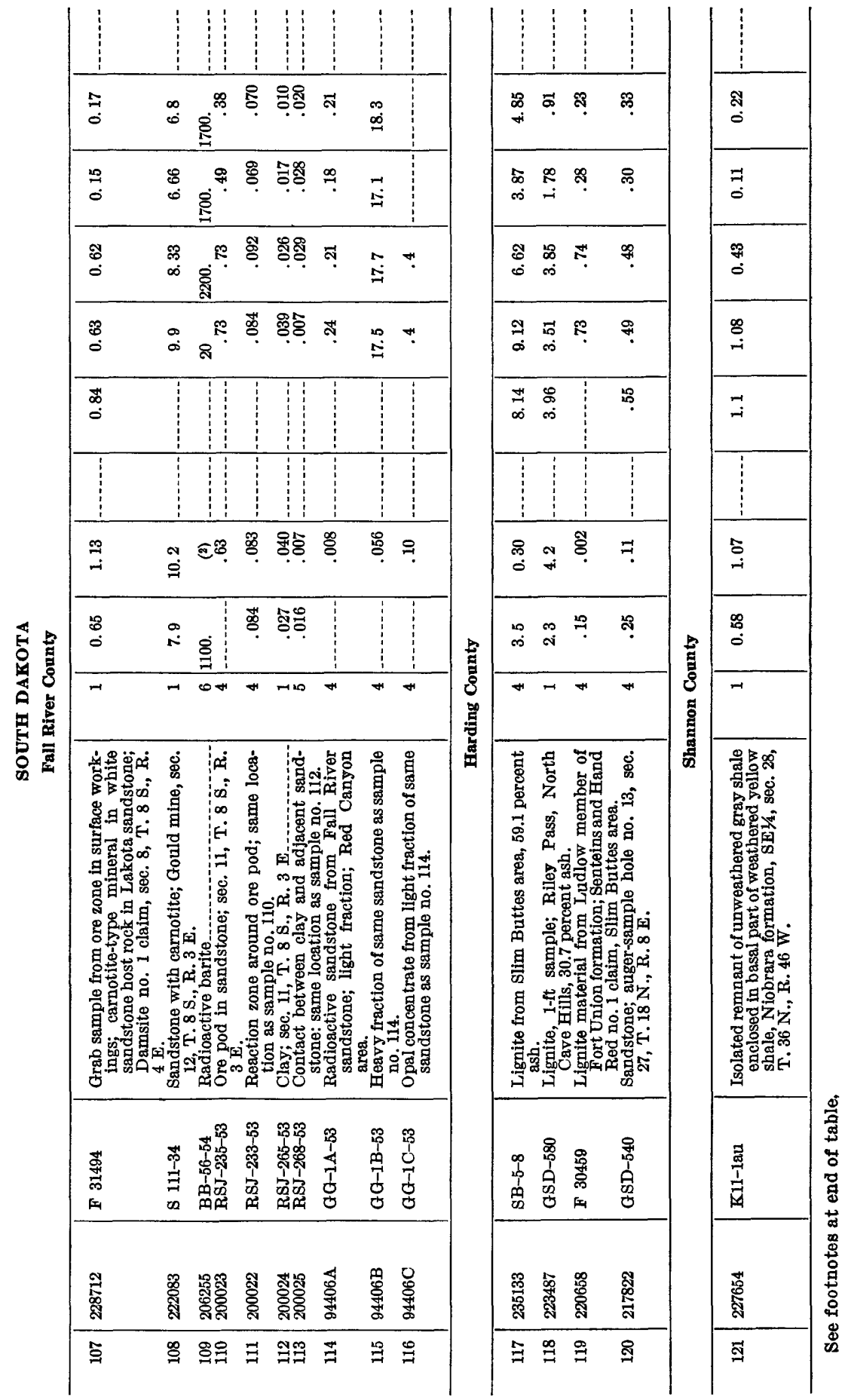




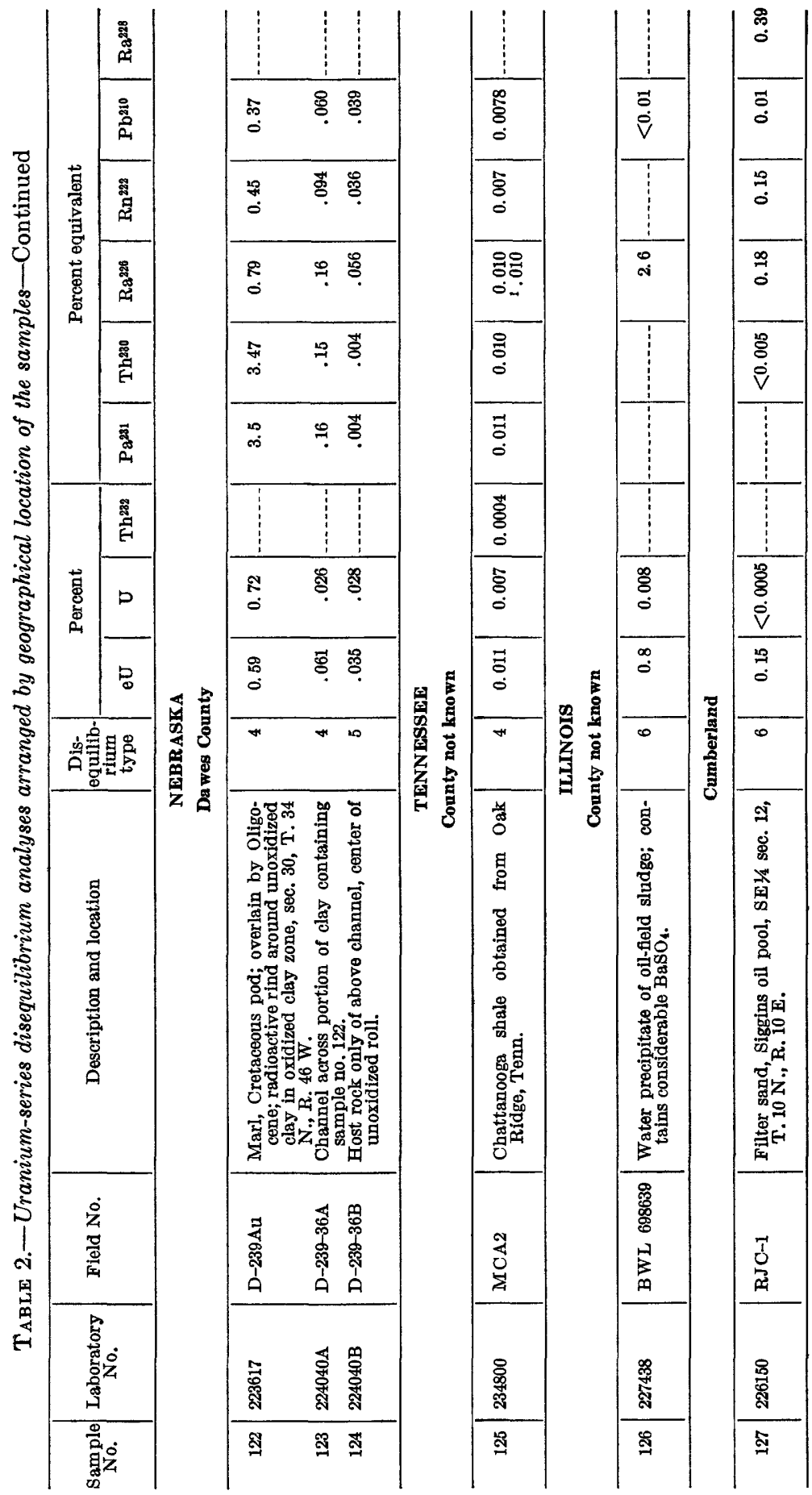




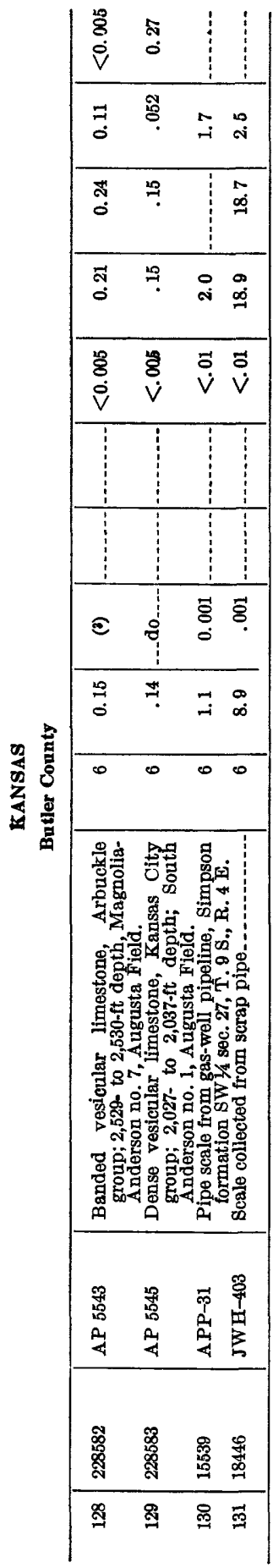

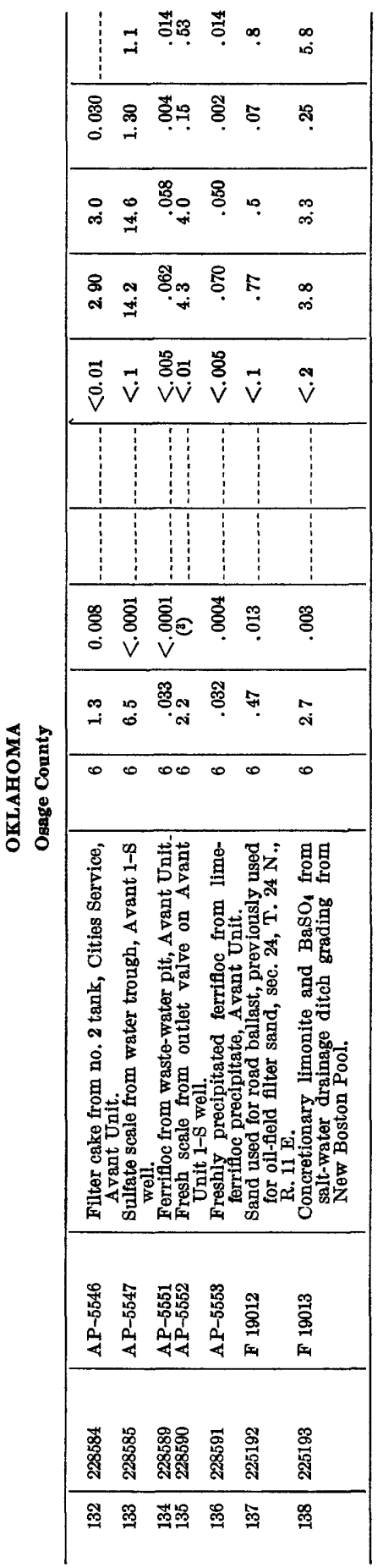

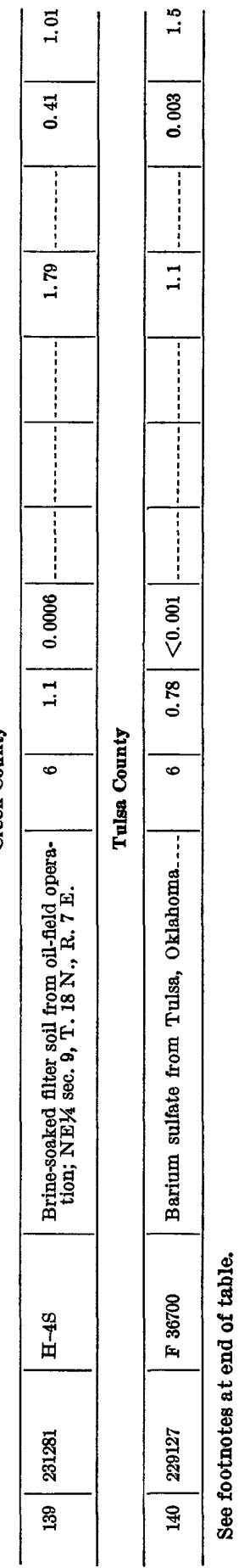




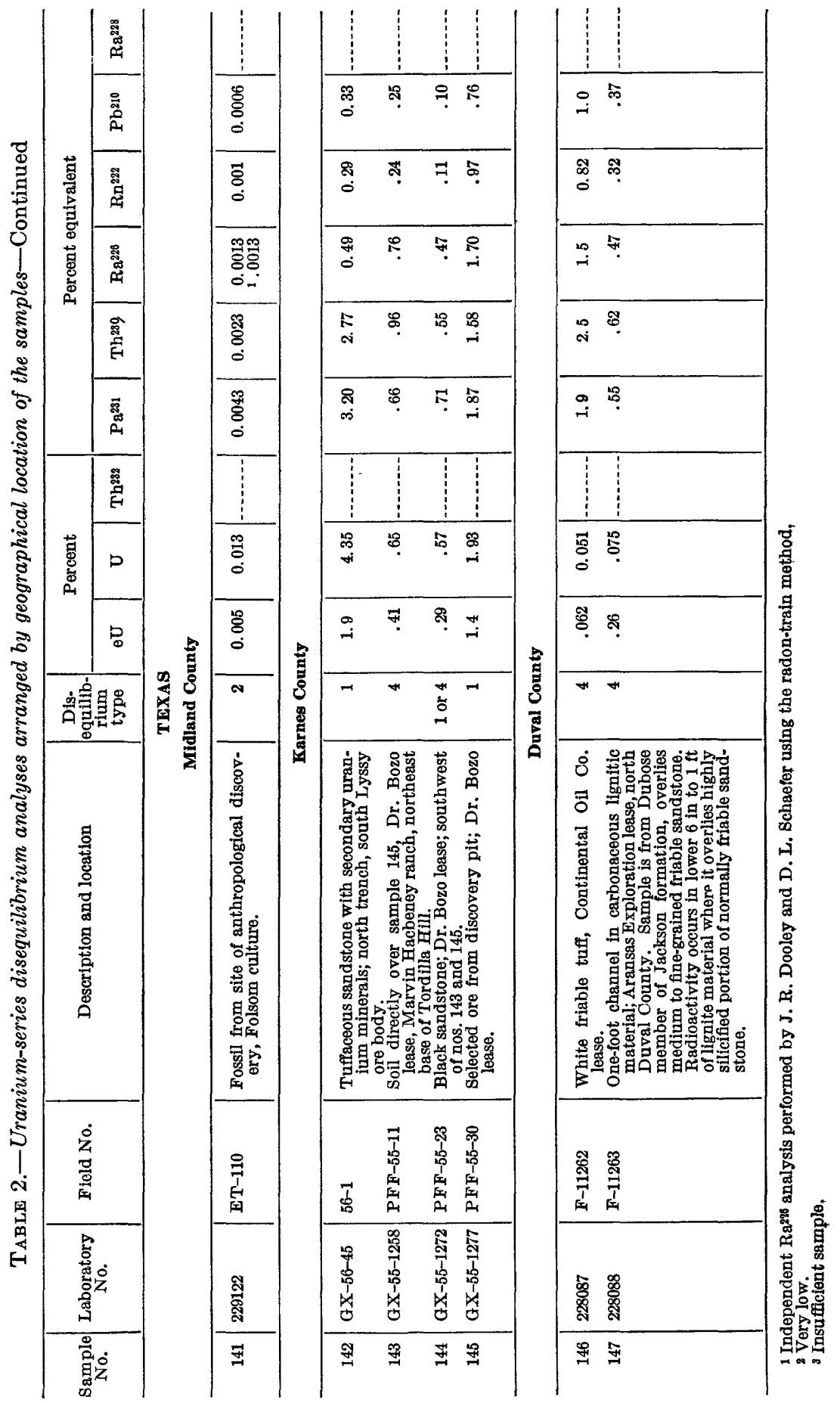




\section{SUMMARY}

Radioactive disequilibrium is a fairly complex phenomenon, and it is not an easy task to provide simple and straightforward explanations for the various daughter-product abundances. An approach through multiple hypotheses whose possible acceptance or rejection will be based on further interpretations provided by geological, geochemical, and chemical evidence will undoubtedly be necessary. The initial goal of this study was to investigate the complexity of disequilibrium and the distribution of its types. Unfortunately many of the early samples that were analyzed did not have adequate enough descriptions to permit more detailed interpretations.

Some of the many possible explanations of the causes of disequilibrium have been presented here although some of these may have to be revised when further evidence is available. Even without acceptance of an hypothesis, radioactive-disequilibrium studies provide important clues to the geological and geochemical history of deposits.

\section{REFERENCES}

Armburst, B. F., Jr., and Kuroda, P. K., 1956, On the isotopic constitution of radium ( $\mathrm{Ra}^{224} / \mathrm{Ra}^{226}$ and $\mathrm{Ra}^{228} / \mathrm{Ra}^{226}$ ) in petroleum brines: Am. Geophys. Union Trans., v. 37, no. 2, p. 216-220.

Barnes, J. W., Lang, E. J., and Potratz, H. A., 1956, Ratio of ionium to uranium in coral limestone: Science, v. 124, p. 175-176.

Chlopin, U. G., and Vernadsky, V. I., 1932, Radium-und mesothoriumbältige naturliche gewasser [Radium and mesothorium content in natural waters]: Zeitschr. Elektrochemie, Band 38, nr. 8a, p. 528-530.

Elson, R. E., 1954, The chemistry of protactinum, in Seaborg, G. T., and Katz, J. J., eds., The actinide elements (Natl. Nuclear Energy Ser., Div. IV, v. 14A): New York, McGraw-Hill Book Co., p. 117.

Gott, G. B., and Hill, J. W., 1953, Radioactivity in some oil fields of southeastern Kansas: U. S. Geol. Survey Bull. 988-E, p. 69-122.

Koczy, F. F., 1954, Geochemical balance in the hydrosphere, in Faul, Henry, ed., Nuclear geology: New York, John Wiley and Sons, Inc., p. 120-127.

Kuroda, P. K., 1955, On the isotopic constitution of radium $\left(\mathrm{Ra}^{223} / \mathrm{Ra}^{220}\right)$ in uranium minerals and recent problems of geochronology: New York Acad. Sci. Annals, v. 62 , art. 8, p. 177-208.

Phair, George, and Levine, Harry, 1953, Notes on the differential leaching of uranium, radium, and lead from pitchblende in $\mathrm{H}_{2} \mathrm{SO}_{4}$ solutions: Econ. Geology, v. 48, p. 358-369.

Rosholt, J. N., Jr., 1954, Quantitative radiochemical method for the determination of major sources of natural radioactivity in ores and minerals: Anal. Chemistry, v. 26, p. 1307-1311.

- 1957a, Patterns of disequilibrium in radioactive ores, in Dunning, J. R., and Prentice, B. R., eds., Advances in nuclear engineering, v. II, pt. 2: New York, Pergamon Press, p. 300-304.

- 1957b, Quantitative radiochemical methods for the determination of the sources of natural radioactivity: Anal. Chemistry, v. 29, p. 1398-1408. 
Rosholt, J. N., Jr., 1958, Radioactive disequilibrium studies as an aid in understanding the natural migration of uranium and its decay products: United Nations Internat. Conf. on the Peaceful Uses of Atomic Energy, 2d, Geneva, 1958, Proc., paper OIC 183, U. N. 772.

Schumb, W. C., Evans, R. D., and Hastings, J. L., 1939, The radioactive determination of protactinium in siliceous terrestrial and meteroric material: Am. Chem. Soc. Jour., v. 61, p. 3451-3455.

Senftle, F. E., Stieff, Lorin, Cuttitta, Frank, and Kuroda, P. K., 1957, Comparison of the isotopic abundance of $U^{235}$ and $U^{238}$ and the radium activity ratios in Colorado Plateau uranium ores: Geochimica et Cosmochimica Acta, v. 11, no. 3, p. 189-193.

Stern, T. W., and Stieff, L. R., 1959, Radium-uranium equilibrium and radiumuranium ages of some Colorado Plateau secondary minerals, in Garrels, R. M., and Larsen, E. P., 3d (compilers), Geochemistry and mineralogy of the Colorado Plateau uranium ores: U. S. Geol. Survey Prof. Paper 320.

Trites, A. F., Jr., and Chew, R. T., 1955, Geology of the Happy Jack mine, White Canyon area, San Juan County, Utah: U. S. Geol. Survey Bull. 1009-H, p. 238.

Urry, W. D., 1948, The radium content of varved clay and a possible age of the Hartford, Connecticut, deposits: Am. Jour. Sci., v. 246, p. 689-700.

Wendorf, Fred, Krieger, A. D., and Albritton, C. C., 1955, The midland discovery, a report on the Pleistocene human remains from Midland, Texas, with a description of the skull by T. D. Stewart: Austin, Texas, Univ. of Texas Press, $139 \mathrm{p}$.

Wildish, J. E., 1930, The origin of protactinium: Am. Chem. Soc. Jour., v. 52, p. 163-177. 




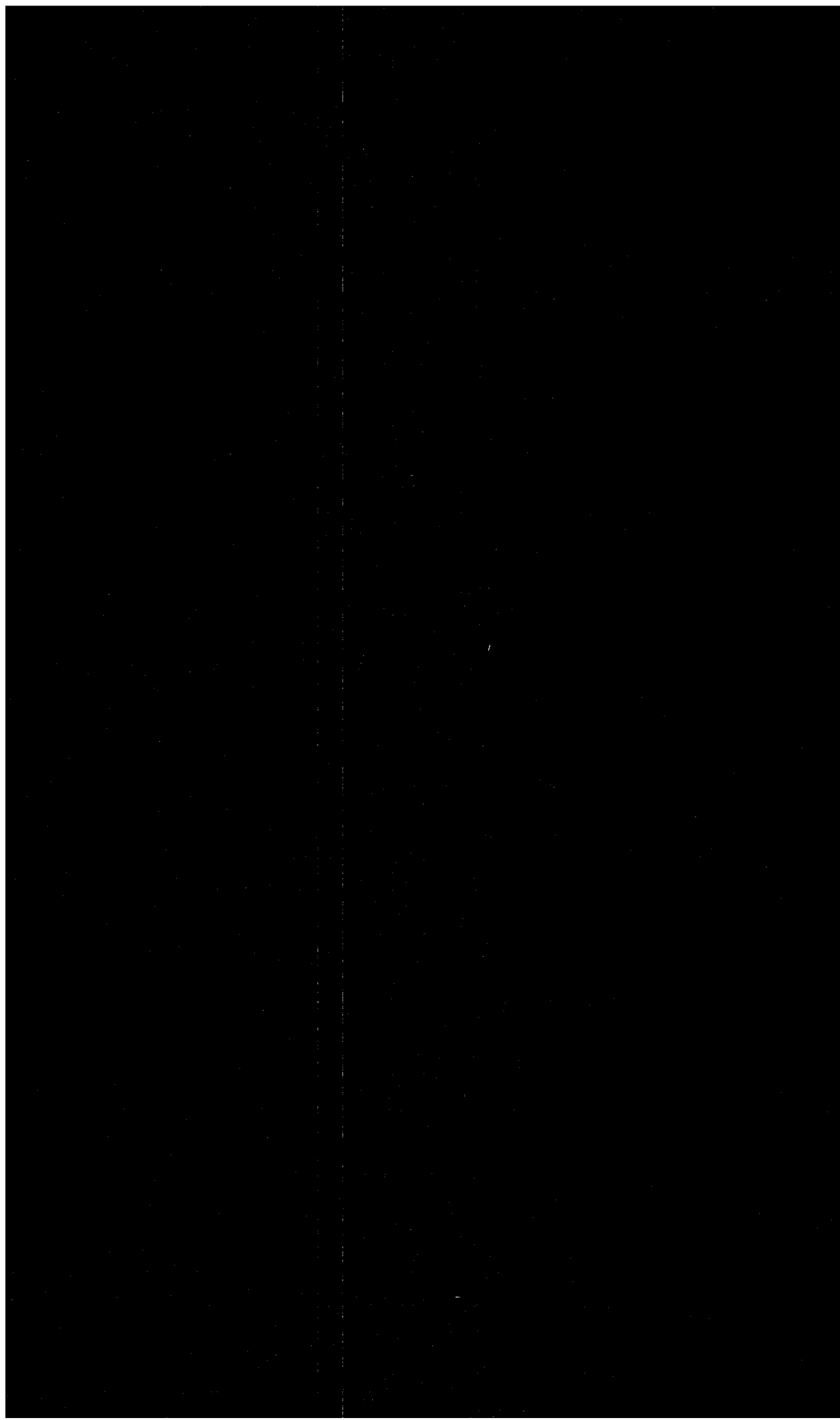




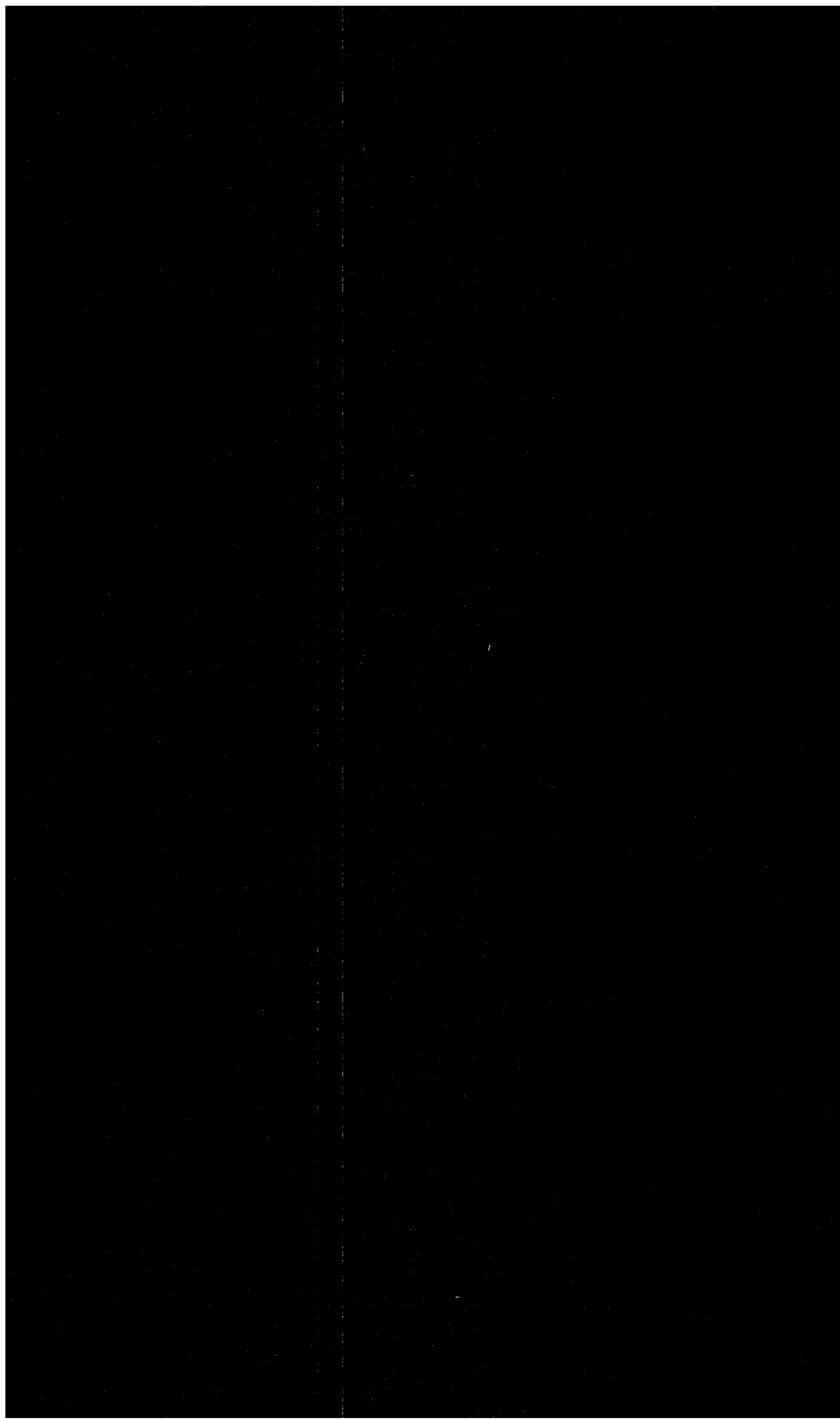

